\title{
Pyoverdine and histicorrugatin-mediated iron acquisition in Pseudomonas thivervalensis
}

\author{
Sandra Matthijs • Nathalie Brandt • \\ Marc Ongena - Wafa Achouak • \\ Jean-Marie Meyer $\cdot$ Herbert Budzikiewicz
}

Received: 20 November 2015/ Accepted: 19 March 2016/Published online: 23 March 2016

(C) Springer Science+Business Media New York 2016

\begin{abstract}
The genome of Pseudomonas thivervalensis LMG $21626^{\mathrm{T}}$ has been sequenced and a genomic, genetic and structural analysis of the siderophore mediated iron acquisition was undertaken. Pseudomonas thivervalensis produces two structurally new siderophores, pyoverdine $\mathrm{PYO}_{\text {thi }}$ which is typical for $P$. thivervalensis strains and a closely related strain, and the lipopeptidic siderophore histicorrugatin which is also detected in $P$. lini. Histicorrugatin consists out of an eight amino acid long peptide which is linked to octanoic acid. It is structurally related to the siderophores corrugatin and ornicorrugatin.
\end{abstract}

Electronic supplementary material The online version of this article (doi:10.1007/s10534-016-9929-1) contains supplementary material, which is available to authorized users.

S. Matthijs $(\bowtie) \cdot$ N. Brandt

Institut de Recherches Microbiologiques-Wiame, Campus

du CERIA, 1 avenue Emile Gryson, bât 4B,

1070 Brussels, Belgium

e-mail: slmatthi@ulb.ac.be

\section{Ongena}

Walloon Center for Industrial Biology, University of Liège/Gembloux Agro-Bio Tech, Gembloux, Belgium

W. Achouak

Laboratory of Microbial Ecology of the Rhizosphere and Extreme Environments (LEMIRE), Aix-Marseille

Université, CEA, CNRS, UMR 7265 Biosciences and

biotechnology Institute of Aix-Marseille (BIAM),

ECCOREV FR 3098, CEA/Cadarache,

St-Paul-Lez-Durance, France
Analysis of the proteome for TonB-dependent receptors identified 25 candidates. Comparison of the TonB-dependent receptors of $P$. thivervalensis with the 17 receptors of its phylogenetic neighbor, $P$. brassicacearum subsp. brassicacearum NFM 421, showed that NFM 421 shares the same set of receptors with $\mathrm{LMG} 21626^{\mathrm{T}}$, including the histicorrugatin receptor. An exception was found for their cognate pyoverdine receptor which can be explained by the observation that both strains produce structurally different pyoverdines. Mass analysis showed that NFM 421 did not produce histicorrugatin, but the analogue ornicorrugatin. Growth stimulation assays with a variety of structurally distinct pyoverdines produced by other Pseudomonas species demonstrated that LMG $21626^{\mathrm{T}}$ and NFM 421 are able to utilize

\footnotetext{
J.-M. Meyer

Département Génétique Moléculaire, Génomique, Microbiologie, UMR, 7156, CNRS/Université LouisPasteur, 28 rue Goethe, 67000 Strasbourg, France

H. Budzikiewicz

Institut für Organische Chemie, Universität zu Köln, Greinstrasse 4, 50939 Cologne, Germany
} 
almost the same set of pyoverdines. Strain NFM 421 is able utilize two additional pyoverdines, pyoverdine of P. fluorescens Pf0-1 and P. citronellolis LMG $18378^{\mathrm{T}}$, these pyoverdines are probably taken up by the FpvA receptor of NFM 421.

Keywords Histicorrugatin - Pyoverdine - TonBdependent receptor - Pseudomonas thivervalensis . Pseudomonas brassicacearum . Genome

\section{Introduction}

Most microorganisms produce siderophores when they are faced with iron-limiting conditions. Fluorescent pseudomonads produce a yellow-green, fluorescent siderophore, called pyoverdine (Meyer and Abdallah 1978). The structures of pyoverdines produced by different strains of fluorescent pseudomonads have been characterized. They are made of three distinct structural parts: a small peptide chain of $\mathrm{L}-$ and D-amino acids (6-14 amino acids depending on the producing strain), linked to a yellow-green chromophore group and a small dicarboxylic acid or its monoamide connected amidically to the $\mathrm{NH}_{2}$-group of the chromophore (Budzikiewicz 1997). Pyoverdines contain catechol, hydroxamic and/or $\beta$-hydroxy amino acid groups that are participating in $\mathrm{Fe}^{3+}$ binding, the chromophore contains one catechol group, and the peptide chain the hydroxamic and $\beta$-hydroxy amino acid groups.

Besides pyoverdine, other secondary siderophores, which have a relatively lower affinity for iron, have been identified in fluorescent pseudomonads (Cornelis and Matthijs 2002). These include pyochelin, pseudomonine and thioquinolobactin (Cox and Graham, 1979; Mercado-Blanco et al. 2001; Matthijs et al. 2004, 2007). In addition the non-fluorescent $P$. corrugata has been reported to produce the lipopeptidic siderophore corrugatin (Risse et al. 1998). Corrugatin consists out of an eight amino acid long peptide which is linked to octanoic acid, an eightcarbon saturated fatty acid (Risse et al. 1998). Ten years after the description of the structure of corrugatin an analogue of corrugatin has been identified and annotated as ornicorrugatin (Matthijs et al. 2008) since the second diaminobutyric acid monomer of corrugatin is replaced by ornithine. Ornicorrugatin was isolated from Pseudomonas sp. AF76 (Matthijs et al. 2008), a Pseudomonas strain belonging to the $P$. fluorescens group. This siderophore is also produced by P. fluorescens SBW25 (Cheng et al. 2013) and a putative ornicorrugatin gene cluster has been proposed to be present in Pseudomonas sp. CH-C52 and P. fluorescens Q8r1-96 (Van Der Voort et al. 2015).

Siderophores trap traces of $\mathrm{Fe}^{3+}$ under the form of very stable complexes. After these siderophore-Fe complexes have been formed, they are internalized into the cells by specific TonB-dependent membrane receptors. Pseudomonas strains are able to use a variety of different siderophores produced by other micro-organisms, including fungi and bacteria (Poole et al. 1990; Jurkevitch et al. 1992; Raaijmakers et al. 1995; Hartney et al. 2011). They can also use heterologous pyoverdines, i.e. structurally different pyoverdines produced by other fluorescent pseudomonads. Growth stimulation assays with heterologous pyoverdines demonstrated that $P$. entomophila L48 ${ }^{\mathrm{T}}, P$. protegens $\mathrm{Pf}-5$ and $P$. fluorescens ATCC 17400 are able to utilize a large variety of structurally distinct pyoverdines (Matthijs et al. 2009; Hartney et al. 2011; Ye et al. 2014a). In contrast, P. putida KT2440 is able to utilize only its own pyoverdine and the pyoverdine produced by $P$. syringae (Matthijs et al. 2009).

In this study we show that under iron limiting conditions $P$. thivervalensis LMG $21626^{\mathrm{T}}$ produces histicorrugatin, a siderophore structurally related to corrugatin and ornicorrugatin. In addition the structure elucidation of a new pyoverdine, $\mathrm{PYO}_{\text {thi }}$, is described. Analysis of the draft genome revealed the putative siderophore biosynthetic and uptake gene clusters which were confirmed through the construction and characterization of mutants. The ability to take up exogenous siderophores was also investigated. Screening of the genome sequence of LMG $21626^{\mathrm{T}}$ for genes coding for TonB-dependent receptors identified 25 candidates. Growth stimulation assays with heterologous pyoverdines demonstrated that $P$. thivervalensis is able to utilize a variety of structurally distinct pyoverdines produced by other Pseudomonas species. The TonB-receptors and the pyoverdine uptake profiles were compared to the ones of the phylogenetically closely related strain $P$. brassicacearum subsp. brassicacearum NFM 421. These were surprisingly similar, reflecting their genetic similarities. 


\section{Materials and methods}

Bacterial strains and growth conditions

The Pseudomonas strains (Table 1) were routinely grown at $28{ }^{\circ} \mathrm{C}$ on an in house medium, medium 853 (Matthijs et al. 2013) or casamino acids (CAA). When required CAA was supplemented with $\mathrm{FeCl}_{3}$ to a final concentration of $50 \mu \mathrm{M}$. Escherichia coli was grown in 853 at $37{ }^{\circ} \mathrm{C}$. The antibiotics chloramphenicol $(\mathrm{Cm})$, kanamycin $(\mathrm{Km})$ and tetracycline $(\mathrm{Tc})$ were used at a concentration of 25,50 and $20 \mu \mathrm{g} \mathrm{ml}^{-1}$, respectively.

Sequencing and annotation of the $P$. thivervalensis LMG $21626^{\mathrm{T}}$ genome

Illumina paired-end sequencing was performed by Beckman Coulter Genomics (UK). The 100 bp reads were de novo assembled using Velvet (Zerbino and Birney 2008) using a minimum contig length cut-off of $1 \mathrm{~kb}$ and various $\mathrm{k}$-mer lengths. This resulted in 59 contigs with in total 58 gaps between scaffolded contigs. The gaps were re-amplified by PCR using Fermentas DreamTaqGreen PCR enzyme. To assemble some of the 59 contigs together, outgoing primers were designed and a PCR was carried out (Fermentas DreamTaqGreen). The amplicons were sequenced using Sanger sequencing technique at Beckman Coulter Genomics (UK). During this work the genome sequence of $P$. thivervalensis DSM $13194^{\mathrm{T}}$ was deposited (accession umber NZ_LHVE00000000.1), some of the contigs were assembled together (order of the contigs) based on that sequence. The draft genome sequence of $P$. thivervalensis LMG $21626^{\mathrm{T}}$ has been deposited at DDBJ/EMBL/GenBank under accession number LRSO00000000. Annotation of open reading frames (ORF) was performed with the NCBI Prokaryotic Automatic Annotation Pipeline (PGAAP).

In silico analyses of siderophore gene clusters and TonB-receptors of $P$. thivervalensis LMG $21626^{\mathrm{T}}$

The gene clusters for pyoverdine and histicorrugatin biosynthesis and transport, and the TonB-receptors of $P$. thivervalensis were found by BLAST homology and search by keywords. The program NRPSpredictor2 (http://www.nrps.informatik.uni-tuebingen.de) which uses the methods of Stachelhaus et al. (1999) and Rausch et al. (2005) was used to predict the peptide backbone of the pyoverdine and histicorrugatin.

Construction of $21626^{\mathrm{T}} \Delta \mathrm{pvdL}, 21626^{\mathrm{T}} \Delta \mathrm{hcs}$, $21626^{\mathrm{T}} \Delta \mathrm{hcsEF}, 21626^{\mathrm{T}} \Delta$ pvdL $\Delta$ hcsEF in-frame deletion mutants of $P$. thivervalensis $\mathrm{LMG} 21626^{\mathrm{T}}$

A pyoverdine-negative deletion mutant was constructed in $P$. thivervalensis LMG $21626^{\mathrm{T}}$ by deleting a 10.9 internal portion of the $13.0 \mathrm{~kb} p v d L$ gene. Therefore, $1 \mathrm{~kb}$ fragments from each of the $5^{\prime}$ - and the $3^{\prime}$-end of $p v d L$ were PCR amplified from LMG $21626^{\mathrm{T}}$ using the primer pairs pvdL-AF and pvdL$\mathrm{AR}$, and pvdL-BF and pvdL-BR (Table 2), respectively. The resulting $5^{\prime}$ - and the $3^{\prime}$-ends were cut with the restriction enzymes HindIII and $X b a \mathrm{I}$ and with $X b a \mathrm{I}$ and EcoRI, respectively, and cloned by triple ligation into EcoRI and HindIII-digested pUK21 $\left(\mathrm{Km}^{\mathrm{R}}\right)$ (pUK-pvdL21626 ${ }^{\mathrm{T}}$ ). The 2055-bp EcoRIHindIII insert was verified by sequencing and recloned into the suicide plasmid pME3087 $\left(\mathrm{Tc}^{\mathrm{R}}\right)$ (pME-pvdL21626 ${ }^{\mathrm{T}}$ ). The resulting plasmid was then integrated into the chromosome of strain LMG $21626^{\mathrm{T}}$ by triparental mating using E. coli HB101/ pME497 as the mobilizing strain, with selection for Tc- and $\mathrm{Cm}$ resistant recombinants. Excision of the vector by a second crossing-over occurred after enrichment for Tc-sensitive cells (Schnider-Keel et al. 2000). The obtained mutant was verified by PCR and checked for loss of fluorescence in the ironlimiting media CAA.

Using the same approach in-frame deletion mutants were constructed for the histicorrugatin biosynthetic genes $h c s E F\left(21626^{\mathrm{T}} \Delta \mathrm{hcsEF}\right)$ and the histicorrugatin receptor $h c s A\left(21626^{\mathrm{T}} \Delta \mathrm{hcs} \mathrm{A}\right)$, with the difference that the upstream and downstream flanking regions of the gene(s) to be deleted were amplified and not the $5^{\prime}$ and $3^{\prime}$ end (Table 2). For the double mutant $21626^{\mathrm{T}-}$ $\Delta$ pvdL $\Delta$ hcsEF the $p v d L$ gene was deleted in the $21626^{\mathrm{T}} \Delta$ hesEF mutant.

\section{Chrome azurol S assay}

Siderophore production was detected by the chromeazurol S (CAS) assay (Schwyn and Neilands 1987). On CAS-agar, siderophores remove iron from CAS, resulting in a blue to yellow-orange color change in zones surrounding the colonies. Therefore, $10 \mu \mathrm{l}$ of an overnight culture adjusted to $\mathrm{OD}_{600}=0.5$ was plated 
Table 1 The strains used in this study

\begin{tabular}{|c|c|c|}
\hline Strain/plasmid & Relevant genotype/characteristics & References \\
\hline \multicolumn{3}{|l|}{ P. thivervalensis } \\
\hline LMG $21626^{\mathrm{T}}$ & $\begin{array}{l}\text { Wild type, isolated from rhizoplane of Brassica napus (Nancy, France), } \\
\text { produces } \text { PYO }_{\text {thi }} \text { and histicorrugatin }\end{array}$ & $\begin{array}{l}\text { Achouak et al. } \\
\text { (2000) }\end{array}$ \\
\hline $21626^{\mathrm{T}} \Delta \mathrm{pvdL}$ & $\begin{array}{l}\text { Pyoverdine-negative deletion mutant of } P \text {. thivervalensis } \mathrm{LMG} 21626^{\mathrm{T}} \text {, } \\
\text { produces histicorrugatin }\end{array}$ & This study \\
\hline $21626^{\mathrm{T}} \Delta \mathrm{hcs} A$ & $\begin{array}{l}\text { Histicorrugatin TonB-receptor (hcsA)-negative deletion mutant of } P \text {. } \\
\text { thivervalensis LMG } 21626^{\mathrm{T}} \text {, produces } \mathrm{PYO}_{\text {thi }} \text { and histicorrugatin }\end{array}$ & This study \\
\hline $21626^{\mathrm{T}} \Delta \mathrm{hcsEF}$ & $\begin{array}{l}\text { Histicorrugatin-negative hcsEF deletion mutant of } P \text {. thivervalensis LMG } \\
21626^{\mathrm{T}} \text {, produces } \mathrm{PYO}_{\text {thi }}\end{array}$ & This study \\
\hline $21626^{\mathrm{T}} \Delta \mathrm{pvdL} \Delta \mathrm{hcsEF}$ & $\begin{array}{l}\text { Pyoverdine/histicorrugatin-negative deletion mutant of } P \text {. thivervalensis LMG } \\
21626^{\mathrm{T}}\end{array}$ & This study \\
\hline P. thivervalensis DR5 & $\begin{array}{l}\text { Endophyte isolated from field-grown Solanum nigrum, produces } \mathrm{PYO}_{\text {thi }} \text { and } \\
\text { histicorrugatin }\end{array}$ & $\begin{array}{l}\text { Long et al. } \\
\qquad(2008)\end{array}$ \\
\hline P. thivervalensis MLG19 & $\begin{array}{l}\text { Isolated from Arabidopsis thaliana (Yvelines Thiverval Grignon, France), } \\
\text { produces } \mathrm{PYO}_{\text {thi }} \text { and histicorrugatin }\end{array}$ & $\begin{array}{l}\text { Achouak et al. } \\
\text { (2000) }\end{array}$ \\
\hline P. thivervalensis MLG39 & $\begin{array}{l}\text { Isolated from Arabidopsis thaliana (Yvelines Thiverval Grignon, France), } \\
\text { produces } \mathrm{PYO}_{\text {thi }} \text { and histicorrugatin }\end{array}$ & $\begin{array}{l}\text { Achouak et al. } \\
\text { (2000) }\end{array}$ \\
\hline P. thivervalensis MLG45 & $\begin{array}{l}\text { Isolated from Arabidopsis thaliana (Yvelines Thiverval Grignon, France), } \\
\text { produces } \mathrm{PYO}_{\text {thi }} \text { and histicorrugatin }\end{array}$ & $\begin{array}{l}\text { Achouak et al. } \\
\text { (2000) }\end{array}$ \\
\hline$P$. thivervalensis $\mathrm{R} 1-4$ & Rhizosphere oilseed rape, produces $\mathrm{PYO}_{\text {thi }}$ & $\begin{array}{l}\text { Gasser et al. } \\
\text { (2009) }\end{array}$ \\
\hline $\begin{array}{l}\text { P. brassicacearum subsp. } \\
\text { brassicacearum NFM } 421\end{array}$ & $\begin{array}{l}\text { Isolated from Arabidopsis thaliana plants growing in soils from Méréville, } \\
\text { France. Produces pyoverdine }\left(\mathrm{PYO}_{\mathrm{ATCC} 39167}\right) \text { and ornicorrugatin }\end{array}$ & $\begin{array}{l}\text { Achouak et al. } \\
\text { (2000) }\end{array}$ \\
\hline NFM421-4D1 & $\begin{array}{l}\text { Pyoverdine-negative } \mathrm{Tn} 5 \text { mutant of } P \text {. brassicacearum subsp. brassicacearum } \\
\text { NFM } 421, \mathrm{Tc}^{\mathrm{R}} \text {, produces ornicorrugatin }\end{array}$ & This study \\
\hline P. brassicacearum BGCR2-9(1) & $\begin{array}{l}\text { Endophyte from field-grown Solanum nigrum, produces } \mathrm{PYO}_{\text {thi }} \text { and } \\
\text { ornicorrugatin }\end{array}$ & $\begin{array}{l}\text { Long et al. } \\
\text { (2008) }\end{array}$ \\
\hline P. lini LMG $21625^{\mathrm{T}}$ & $\begin{array}{l}\text { Isolated from rhizosphere soil of Dijon (Linum usitatissinum), produces } \\
\text { pyoverdine and histicorrugatin }\end{array}$ & $\begin{array}{l}\text { Delorme et al. } \\
\text { (2002) }\end{array}$ \\
\hline Pseudomonas sp. GM50 & Isolated from root of Populus deltoides & $\begin{array}{l}\text { Brown et al. } \\
\text { (2012) }\end{array}$ \\
\hline pUK21 & Cloning vector; lacZ $\alpha ; \mathrm{Km}^{\mathrm{R}}$ & $\begin{array}{l}\text { Vieira and } \\
\text { Messing } \\
(1991)\end{array}$ \\
\hline pME3087 & Suicide vector, ColE1 replicon, RK2-Mob, $\mathrm{Tc}^{\mathrm{R}}$ & $\begin{array}{l}\text { Voisard et al. } \\
\text { (1994) }\end{array}$ \\
\hline pME-pvdL & pME3087 containing the $5^{\prime}$ and $3^{\prime}$ end of $p v d L, \mathrm{Tc}^{\mathrm{R}}$ & This study \\
\hline pME-hcsA & pME3087 containing the $5^{\prime}$ and $3^{\prime}$ flanking regions of $h c s A, \mathrm{Tc}^{\mathrm{R}}$ & This study \\
\hline pME-hcsEF & pME3087 containing the $5^{\prime}$ and $3^{\prime}$ flanking regions of $h c s E F, \mathrm{Tc}^{\mathrm{R}}$ & This study \\
\hline
\end{tabular}

on CAA-CAS agar, kept at $28^{\circ} \mathrm{C}$ for $48 \mathrm{~h}$ and the size of the halo was measured.

Large scale purification of $\mathrm{PYO}_{\mathrm{thi}}$ and histicorrugatin of $P$. thivervalensis $\mathrm{LMG}$ $21626^{\mathrm{T}}$

Pyoverdine and histicorrugatin were purified from $72 \mathrm{~h}$ old culture supernatant of respectively $P$. thivervalensis $\mathrm{LMG} 21626^{\mathrm{T}}$ and the pyoverdinenegative mutant $21626^{\mathrm{T}} \Delta \mathrm{pvdL}$, grown at $28^{\circ} \mathrm{C}$ in three 41 Erlenmeyer flasks containing 11 of iron-poor CAA medium at $200 \mathrm{rpm}$. Bacterial cells were removed by centrifugation at $10,000 \mathrm{~g}$ during $15 \mathrm{~min}$. After filtration the supernatant was passed on a C-18 column that was activated with methanol and washed with distilled water. Elution was done with acetonitrile $/ \mathrm{H}_{2} \mathrm{O}(70 / 30 \%)$. Most of the acetonitrile was 
Table 2 The primers, and their sequence, used for the amplification of fragment $A$ and $\mathrm{B}$ for the construction of plasmid pUKpvdL21626 ${ }^{\mathrm{T}}$, pUKhcsA21626 ${ }^{\mathrm{T}}$ and pUKhcsEF $21626^{\mathrm{T}}$ are given
Restriction enzymes sites are italics. In addition the primers, and their sequence, used to confirm the obtained deletions $\Delta$ pvdL, $\Delta$ hcsA and $\triangle \mathrm{hcsEF}$ (verification deletion) are given

\begin{tabular}{|c|c|}
\hline Primer name & Primer sequence \\
\hline \multicolumn{2}{|c|}{ Plasmid pUK-pvdL21626 ${ }^{\mathrm{T}}$} \\
\hline \multicolumn{2}{|c|}{ Amplification of fragment $\mathrm{A}(\mathrm{AF}$ and $\mathrm{AR})$ and $\mathrm{B}(\mathrm{BF}$ and $\mathrm{BR})$ : } \\
\hline pvdL-AF & 5'-GTGAAGCTTGACCGACGCGTTCGAACT-3' \\
\hline pvdL-AR & 5'-GTGTCTAGAACCCGCAACGAAGGAATG-3' \\
\hline pvdL-BF & 5'-GTGTCTAGAAGCGATGCCACCGGAACT-3' \\
\hline pvdL-BR & 5'-GTGGAATTCCCTCCAACTCCGCCATCA-3' \\
\hline \multicolumn{2}{|c|}{ Verification primers of deletion } \\
\hline pvdL-delF & 5'-CACGATCTGGAACAGGTAACT-3' \\
\hline pvdL-delR & 5'-TGGCCTTGGTCCAGGTAGT-3' \\
\hline \multicolumn{2}{|c|}{ Plasmid pUK-hcsA21626 ${ }^{\mathrm{T}}$} \\
\hline \multicolumn{2}{|c|}{ Amplification of fragment $\mathrm{A}(\mathrm{AF}$ and $\mathrm{AR})$ and $\mathrm{B}(\mathrm{BF}$ and $\mathrm{BR})$ : } \\
\hline hesA-AF & 5'-GTGAAGCTTCACTGGCCTTGATGCAATG-3' \\
\hline hesA-AR & 5'-GTGTCTAGAGCCAACGCAATTGTGTTCT-3' \\
\hline hcsA-BF & 5'-GTGTCTAGACCTGCGCTACGACATGTAA-3' \\
\hline hesA-BR & 5'-GTGGAATTCCGACAGGTTGCCGCTGAT-3' \\
\hline \multicolumn{2}{|c|}{ Verification deletion } \\
\hline hesA-delF & 5'-GTCCTGGCAGTAGCGTTCA-3' \\
\hline hcsA-delR & 5'-CGTTCAATGTGACCGCTTGA-3' \\
\hline \multicolumn{2}{|c|}{ Plasmid pUK-hcsEF21626 } \\
\hline \multicolumn{2}{|c|}{ Amplification of fragment $\mathrm{A}(\mathrm{AF}$ and $\mathrm{AR})$ and $\mathrm{B}(\mathrm{BF}$ and $\mathrm{BR})$ : } \\
\hline hcsEF-AF & 5'-GTGAAGCTTGCAAGGCATGACCTTGTTCA-3' \\
\hline hcsEF-AR & 5'-GTGCTGCAGCACGATAGACATAATGGCATC-3' \\
\hline hcsEF-BF & 5'-GTGCTGCAGGACGAGGCCAACCTGTGAA-3' \\
\hline hcsEF-BR & 5'-GTGTCTAGACTGCTCGTCGAGGTGAATC-3' \\
\hline \multicolumn{2}{|c|}{ Verification deletion } \\
\hline hcsEF-delF & 5'-GCAGCATGACCTGCTGTTGA-3' \\
\hline hcsEF-delR & 5'-GTTGATGAACAGGCCGATCA-3' \\
\hline
\end{tabular}

evaporated with a rotavapor and the samples were lyophilized.

Preparative-scale purification was done on a Prep 150 LC system (Waters). A SunFire Prep C18 column $(\mathrm{C}-18,19 \times 250 \mathrm{~mm}, 5 \mu \mathrm{m}$ particle size) was used with a flow rate of $20 \mathrm{ml} / \mathrm{min}$ and a gradient going from $\mathrm{H}_{2} \mathrm{O} / \mathrm{CH}_{3} \mathrm{CN}$ 9:1 containing $0.1 \% \mathrm{CF}_{3} \mathrm{COOH}$ to $\mathrm{H}_{2} \mathrm{O} / \mathrm{CH}_{3} \mathrm{CN}$ 2:8 containing $0.1 \% \mathrm{CF}_{3} \mathrm{COOH}$ in $30 \mathrm{~min}$. From the extract $\mathrm{CH}_{3} \mathrm{CN}$ was evaporated in vacuo and the sample was lyophilized.

LC/MS analyses were performed on a Kontron 325 system, coupled to the mass spectrometer and equipped with a UV detector (model 322), an automatic injector (model 465) and LC-6A type pumps. The column used was a Vydac 218TP54 RP column $\left(\mathrm{C}_{18}, 5 \mu \mathrm{m}, \mathrm{d}=0.46 \mathrm{~cm}, 1=25 \mathrm{~cm}\right)$ and a flow rate of $1 \mathrm{ml} / \mathrm{min}$ was maintained. Mass spectral data (MS) were recorded on a VG Quattro II spectrometer (ESP ionization, cone voltage $70 \mathrm{~V}$, capillary voltage $3.5 \mathrm{kV}$, source temperature $80^{\circ} \mathrm{C}$ ). Data collection was done with Masslynx software.

Amplification and sequencing of housekeeping genes of non type $P$. thivervalensis strains

The almost complete 16S rRNA gene sequence (position 29-1522 in E. coli) of non type P. thivervalensis strains and $P$. brassicacearum BGCR2-9(1) was amplified with primers $\mathrm{pA}$ and $\mathrm{pH}$ (Edwards et al. 1989). Part of the housekeeping genes gyrB and $r p o D$ was amplified using primers UP1E/APrU (Yamamoto et al. 2000) and PsEG30F/PsEG790R (Mulet et al. 2009), respectively. The PCR was carried out in a final volume of $25 \mu \mathrm{l}$ containing PCR buffer (Qiagen) with 
0.625 U Taq DNA polymerase (Qiagen), $5 \mu \mathrm{l}$ Q-solution (Qiagen), the deoxynucleotide mixture at $100 \mu \mathrm{M}$ (Fermentas), each of the primers at $0.5 \mu \mathrm{M}$ (Sigma) and 1-2 $\mu$ l template DNA. Template DNA for PCR reaction was purified using the DNeasy Blood and Tissue kit of Qiagen. The PCR program used was an initial denaturation of $2 \mathrm{~min}$ at $94{ }^{\circ} \mathrm{C}$, followed by 40 cycles of denaturation at $94{ }^{\circ} \mathrm{C}$ for $30 \mathrm{~s}$, annealing at $55{ }^{\circ} \mathrm{C}$ for $30 \mathrm{~s}$ and extension at $72{ }^{\circ} \mathrm{C}$ for $90 \mathrm{~s}$ for $16 \mathrm{~S}$ rRNA, and $50 \mathrm{~s}$ for $\mathrm{gyrB}$ and $r p o D$, followed by an incubation for $10 \mathrm{~min}$ at $72{ }^{\circ} \mathrm{C}$. The obtained PCR fragments were purified and sequenced at Beckman Coulter Genomics (UK) using amplification and internal primers (for 16S rRNA).

Phylogenetic analysis

Phylogenetic analysis based on concatenated almost complete 16S rRNA gene sequences and partial gyrB and $r p o D$ genes was performed using CLUSTALX and MEGA v5.0 (Tamura et al. 2011). The neighborjoining method was used with the Jukes-Cantor model and topological robustness was evaluated by bootstrap analysis based on 1.000 replicates. The 16S rRNA, gyr $B$ and $r p o D$ gene sequences of the type strains were taken from GenBank.

Using neighbor-joining analysis an unrooted tree was generated from the amino acid sequences of the TonB-dependent receptors of $P$. thivervalensis $\mathrm{LMG}$ $21626^{\mathrm{T}}$ and $P$. brassicacearum subsp. brassicacearum NFM 421, with bootstrap support from 500 resampled datasets. The TonB-dependent receptors were identified by means of search by keywords including TonB, receptor, ligand gated channel and siderophore, and blast analysis.

Histicorrugatin gene cluster of Pseudomonas sp. GM50

The putative histicorrugatin gene cluster of Pseudomonas sp. GM50 was located on two different contigs, AKJK00000000 (5' part) and AKJK01000000 ( $3^{\prime}$ part). By means of PCR with primers GM50-F1 (5'CCGCTGTTCCAGGTGATGT- $\left.3^{\prime}\right)$ and GM50-R3 (5'-GCTTCGTCGAGGATGTACA-3') using DreamTaqGreen (Fermentas) an amplicon with the sequence linking both contigs together was obtained. The amplicon was sequenced (accession number KT748760 gives the sequence of the fragment after removal of the overlapping sequence of the contigs) and the fragments AKJK00000000, KT748760 and AKJK01000000 were concatenated.

Plasposon mutagenesis of $P$. brassicacearum NFM 421

The plasposon mutagenesis method (Dennis and Zylstra 1998) was used to generate transposon insertions in the chromosome of $P$. brassicacearum NFM 421. Mid-log phase cultures of E. coli SM10 ( $\lambda$ pir), the host of the plasposon pTnmod-OTc, was mixed with strain NFM 421 in a $1: 1$ ratio. $P$. brassicacearum was kept at $37{ }^{\circ} \mathrm{C}$ for $1 \mathrm{~h}$ just before mixing of both strains in order to inactive its restriction system. After overnight incubation on 853 at $28^{\circ} \mathrm{C}$, transposon insertions in strain $P$. brassicacearum were selected on CAA supplemented with $50 \mu \mathrm{g} \mathrm{ml}^{-1} \mathrm{Tc}$ and $20 \mu \mathrm{g} \mathrm{ml}^{-1} \mathrm{Cm}$. A bank of 728 transconjugants was screened for mutants with a reduced or loss of the ability to produce pyoverdine as detected by reduction or loss of fluorescence. The mutants were characterized molecularly as described in (Matthijs et al. 2009).

Pyoverdine typing through IEF and mass analysis

The pyoverdine of the Pseudomonas strains (Table 3) was purified using the medium scale method as described in Matthijs et al. (2009). Pyoverdineisoelectrofocusing was done with the Clean Gel IEF from GE Healthcare. For ampholines Pharmalyte $\mathrm{pH} 3$ till 10 was used (GE Healthcare). The gel was prepared according the manufactor instructions with following minor modifications; the rehydradation of the gel was done with double volume and the ampholines concentration was increased by $25 \%$.

Utilization of exogenous pyoverdines by $P$. thivervalensis LMG $21626^{\mathrm{T}}$ and $P$. brassicacearum subsp. brassicacearum NFM 421

Twenty ml CAA agar plates containing $400 \mu \mathrm{M}$ of 2,2-dipyridyl were overlaid with $5 \times 10^{7}$ cells of a fresh culture of the mutant $21626^{\mathrm{T}} \Delta \mathrm{pvdL} \Delta \mathrm{hcsEF}$ or NFM421-4D1, and filter-paper disks impregnated with $20 \mu \mathrm{l}$ of $8 \mathrm{mM}$ or $5 \mu \mathrm{l}$ of $32 \mathrm{mM}$ purified pyoverdine were placed on the agar. The plates were subsequently incubated at $28{ }^{\circ} \mathrm{C}$ and scored for the 
Table 3 List of strains with the type of pyoverdine produced

\begin{tabular}{|c|c|c|c|c|}
\hline \multirow{2}{*}{$\begin{array}{l}\text { Strain pyoverdine isolated } \\
\text { from }\end{array}$} & \multicolumn{2}{|l|}{ Cross-feeding } & \multirow{2}{*}{$\begin{array}{l}\text { Composition of pyoverdine peptide } \\
\text { chain or siderotype }\end{array}$} & \multirow[t]{2}{*}{ References or source } \\
\hline & $21626^{\mathrm{T}} \Delta \mathrm{pvdL} \Delta \mathrm{hcsEF}$ & NFM421-4D1 & & \\
\hline \multicolumn{5}{|l|}{ Six amino acids } \\
\hline P. koreensis LMG $21318^{\mathrm{T}}$ & - & - & $\begin{array}{l}\text { Ala-Lys-Thr-Ser-AOHOrn- } \\
\text { cOHOrn }^{\mathrm{a}}\end{array}$ & $\begin{array}{l}\text { This study, } \\
\text { Budzikiewicz et al. } \\
\text { (1992) }\end{array}$ \\
\hline P. lini W2Aug36 & + & + & $\begin{array}{l}\text { eLys-OHAsp-Ala-aThr-Ala- } \\
\text { cOHOrn }\end{array}$ & Matthijs et al. (2009) \\
\hline \multicolumn{5}{|l|}{ Seven amino acids } \\
\hline P. aeruginosa 7NSK2 & + & + & $\begin{array}{l}\text { Ser-FOHOrn-Orn-Gly-aThr-Ser- } \\
\text { cOHOrn }{ }^{\mathrm{a}} \\
\text { (Type II pyoverdine) }\end{array}$ & $\begin{array}{l}\text { This study, Tappe } \\
\text { et al. (1993) }\end{array}$ \\
\hline P. libanensis LMG $21606^{\mathrm{T}}$ & - & - & $\begin{array}{l}\text { Ala-Orn-OHAsp-Ser-Orn-Ser- } \\
\text { cOHOrn }\end{array}$ & Meyer et al. (2008) \\
\hline P. putida BTP2 & - & - & $\begin{array}{l}\text { Ser-Val-OHAsp-Gly-Thr-Ser- } \\
\text { cOHOrn }\end{array}$ & Ongena et al. (2001) \\
\hline P. putida KT 2440 & - & - & $\begin{array}{l}\text { Asp-Orn-(OHAsp-Dab)-Gly-Ser- } \\
\text { cOHOrn }\end{array}$ & Matthijs et al. (2009) \\
\hline $\begin{array}{l}\text { Pseudomonas sp. } \\
\text { W15Feb38 }\end{array}$ & + & + & $\begin{array}{l}\text { Ser-AOHOrn-Ala-Gly-aThr-Ala- } \\
\text { cOHOrn }\end{array}$ & Matthijs et al. (2009) \\
\hline \multicolumn{5}{|l|}{ Eigth amino acids } \\
\hline P. aeruginosa $\mathrm{PAO} 1$ & - & - & $\begin{array}{l}\text { Ser-Arg-Ser-FOHOrn-(Lys- } \\
\text { FOHOrn-Thr-Thr) } \\
\text { (Type I pyoverdine) }\end{array}$ & Briskot et al. (1989) \\
\hline $\begin{array}{l}\text { P. brassicacearum subsp. } \\
\text { brassicacearum NFM } \\
421\end{array}$ & \pm & + & $\begin{array}{l}\text { Ser-AOHOrn-Ala-Gly-(Ser-Ala- } \\
\text { OHAsp-Thr) }\end{array}$ & $\begin{array}{l}\text { This study, Uría- } \\
\text { Fernández et al. } \\
\text { (2003) }\end{array}$ \\
\hline P. chlororaphis D-TR133 & + & + & $\begin{array}{l}\text { Asp-FOHOrn-Lys-(Thr-Ala-Ala- } \\
\text { FOHOrn-Ala) }\end{array}$ & $\begin{array}{l}\text { Barelmann et al. } \\
\text { (2003) }\end{array}$ \\
\hline P. fluorescens Pf-5 & + & + & $\begin{array}{l}\text { Asp-FOHOrn-Lys-(Thr-Ala-Ala- } \\
\text { FOHOrn-Lys) }\end{array}$ & Matthijs et al. (2009) \\
\hline P. salomonii LMG $22120^{\mathrm{T}}$ & + & + & $\begin{array}{l}\text { Ser-Orn-FOHOrn-Ser-Ser-(Lys- } \\
\text { FOHOrn-Ser) }^{\mathrm{a}}\end{array}$ & $\begin{array}{l}\text { This study, Schlegel } \\
\text { et al. }(2001)\end{array}$ \\
\hline \multicolumn{5}{|l|}{ Nine amino acids } \\
\hline P. fluorescens Pf0-1 & - & + & $\begin{array}{l}\text { Ala-AcOHOrn-Orn-Ser-Ser-Ser- } \\
\text { Arg-OHAsp-Thr }\end{array}$ & Meyer et al. (2008) \\
\hline P. lurida LMG $21995^{\mathrm{T}}$ & + & + & $\begin{array}{l}\text { Ser-Ser-FOHOrn-Ser-Ser-(Lys- } \\
\text { FOHOrn-Lys-Ser) }^{\mathrm{a}}\end{array}$ & $\begin{array}{l}\text { This study, Sultana } \\
\text { et al. (2000) }\end{array}$ \\
\hline $\begin{array}{l}\text { P. costantinii LMG } \\
22119^{\mathrm{T}}\end{array}$ & + & + & $\begin{array}{l}\text { Ser-AOHOrn-Gly-aThr-Thr-Gln- } \\
\text { Gly-Ser-cOHOrn }^{\text {a }}\end{array}$ & $\begin{array}{l}\text { This study, } \\
\text { Fernández et al. } \\
\text { (2001) }\end{array}$ \\
\hline $\begin{array}{l}\text { P. thivervalensis } \mathrm{LMG} \\
21626^{\mathrm{T}}\end{array}$ & + & + & $\begin{array}{l}\text { Ala-AcOHOrn-Gly-Thr-Thr-Gln- } \\
\text { Gly-Ser-cOHOrn }\end{array}$ & This study \\
\hline \multicolumn{5}{|l|}{ Ten amino acids } \\
\hline P. brenneri LMG $23068^{\mathrm{T}}$ & - & - & $\begin{array}{l}\text { Ser-Dab-Gly-Ser-OHAsp-Ala-Gly- } \\
\text { Ala-Gly-cOHOrn }\end{array}$ & Matthijs et al. (2009) \\
\hline P. entomophila $\mathrm{L}_{4} 8^{\mathrm{T}}$ & - & - & $\begin{array}{l}\text { Ala-Asn-Dab-OHHis-Gly-Gly-Ala- } \\
\text { Thr-Ser-cOHOrn }\end{array}$ & Matthijs et al. (2009) \\
\hline P. fluorescens DSM 50106 & - & - & $\begin{array}{l}\text { Ser-Lys-Gly-FOHOrn-Ser-Ser- } \\
\text { Gly-(Orn-FOHOrn-Ser) }\end{array}$ & Meyer et al. (2008) \\
\hline
\end{tabular}


Table 3 continued

\begin{tabular}{|c|c|c|c|c|}
\hline \multirow{2}{*}{$\begin{array}{l}\text { Strain pyoverdine isolated } \\
\text { from }\end{array}$} & \multicolumn{2}{|l|}{ Cross-feeding } & \multirow{2}{*}{$\begin{array}{l}\text { Composition of pyoverdine peptide } \\
\text { chain or siderotype }\end{array}$} & \multirow[t]{2}{*}{ References or source } \\
\hline & $21626^{\mathrm{T}} \Delta \mathrm{pvdL} \Delta \mathrm{hcsEF}$ & NFM421-4D1 & & \\
\hline P. rhodesiae LMG $17764^{\mathrm{T}}$ & + & + & $\begin{array}{l}\text { Ser-Lys-FOHOrn-Ser-Ser-Gly- } \\
\quad(\text { Lys-FOHOrn-Ser-Ser) }\end{array}$ & $\begin{array}{l}\text { This study, } \\
\text { Budzikiewicz } \\
\text { (2004) }\end{array}$ \\
\hline
\end{tabular}

Twelve amino acids

\begin{tabular}{|c|c|c|c|c|}
\hline $\begin{array}{l}\text { Pseudomonas sp. } \\
\text { W15Oct } 28\end{array}$ & - & - & $\begin{array}{l}\text { Asp-Ala-AOHOrn-Thr-Gly-c(Thr- } \\
\text { (O)-Hse-Hya-Ser-Orn-Hse-Ser-O) }\end{array}$ & Ye et al. (2013) \\
\hline \multicolumn{5}{|l|}{ Unknown structures } \\
\hline P. agarici $\mathrm{LMG} 2112^{\mathrm{T}}$ & + & + & & \\
\hline P. asplenii $\mathrm{LMG} 21749^{\mathrm{T}}$ & - & - & & \\
\hline P. cedrina $\mathrm{LMG} 23661^{\mathrm{T}}$ & - & - & & \\
\hline P. chlororaphis W2Apr9 & + & + & & \\
\hline $\begin{array}{l}\text { P. citronellolis } \mathrm{LMG} \\
18378^{\mathrm{T}}\end{array}$ & - & + & & \\
\hline P. fluorescens LMG 14562 & - & - & & \\
\hline P. mosselii LMG $21539^{\mathrm{T}}$ & - & - & & \\
\hline $\begin{array}{l}\text { Pseudomonas sp. } \\
\text { W2Jun14 }\end{array}$ & - & - & & \\
\hline $\begin{array}{l}\text { Pseudomonas sp. } \\
\text { W15Apr2 }\end{array}$ & + & + & & \\
\hline $\begin{array}{l}\text { Pseudomonas sp. } \\
\text { W15Oct11 }\end{array}$ & - & - & & \\
\hline
\end{tabular}

Abbreviations used for uncommon amino acids, three letter code; aThr allo-Thr, eLys Lys linked by its e-NH $\mathrm{N}_{2}$ AOHOrn $\delta \mathrm{N}_{-}$acetyl$\delta \mathrm{N}$-hydroxy-ornithine, FOHOrn $\delta \mathrm{N}$-formyl- $\delta \mathrm{N}$-hydroxy-ornithine, $c O H O r n$ cyclo-hydroxy-ornithine (3-amino-1-hydroxypiperidone-2), OHHis threo- $\beta$-hydroxy-histidine, OHAsp threo- $\beta$-hydroxy-aspartic acid, Dab diamino-butanoic acid. Cyclic pyoverdines are indicated by parentheses

a The structure was deduced from the observation that the IEF profile and the mass of the pyoverdine was identical to the relevant reference strain

presence of detectable growth of the pyoverdinenegative mutant after 1 and 2 days.

\section{Results}

\section{P. thivervalensis LMG $21626^{\mathrm{T}}$ produces a new pyoverdine $\mathrm{PYO}_{\text {thi }}$}

From $P$. thivervalensis MLG45 a pyoverdine was isolated for which only the molecular mass, 1261 determined by mass spectrometry, has been reported (Meyer et al. 2008). A detailed study of the electrospray mass spectra (Budzikiewicz et al. 2007) allows to present the amino acid sequence of the pyoverdine: Ala-AcOHOrn-Gly-(a)Thr-(a)Thr-Gln-Gly-SercOHOrn. Two isoforms were observed, for one of them with a succinamide (Suca) residue attached to the chromophore (Chr) the typical pattern for a Suca-ChrAla N-terminus was obtained by collision induced fragmentation of $[\mathrm{M}+2 \mathrm{H}]^{2+}$ as well as the sequence of b-ions (cleavage of the amide bonds) (Table 4). A differentiation between Thr and aThr is not possible, nor can the chirality of the amino acids be determined. A second isoform with malamide (Mala) attached to Chr yields $[\mathrm{M}+\mathrm{H}]^{+}$with a mass of 1277 and $\mathrm{a}_{1}$ shifted to 416 and losing 115 Da (Mala) instead of 99 Da (Suca). Through IEF and mass analysis the pyoverdine of LMG $21626^{\mathrm{T}}$ was compared to the one of MLG45. Based on these results the pyoverdine structures of MLG45 and LMG $21626^{\mathrm{T}}$ are identical.

To verify whether this pyoverdine is typical for $P$. thivervalensis, i.e. do they belong to the same siderotype (Meyer et al. 2002), 3 additional $P$. thivervalensis strains (Table 1), including 2 isolates (MLG19 and MLG39) from Arabidopsis thaliana 
Table 4 Mass spectrometry data allowing a peptide chain structure proposal for $\mathrm{PYO}_{\text {thi }}$ of $P$. thivervalensis MLG45

\begin{tabular}{lcccc}
\hline & $m / z$ value & $-\mathrm{NH}_{3}$ & $-\mathrm{H}_{2} \mathrm{O}$ & $-\mathrm{CH}_{2} \mathrm{CO}$ \\
\hline $\mathrm{A}_{1}$ & 400 & 383 & 382 & \\
$\mathrm{~B}_{1}$ & 428 & & 410 & \\
$\mathrm{~B}_{2}$ & 600 & 583 & 582 & 558 \\
$\mathrm{~B}_{3}$ & 657 & & 639 & \\
$\mathrm{~B}_{4}$ & 758 & & 740 & \\
$\mathrm{~B}_{5}$ & 859 & 841 & \\
$\mathrm{~B}_{6}$ & 987 & & 969 & \\
$\mathrm{~B}_{7}$ & 1044 & & 1026 & \\
$\mathrm{~B}_{8}$ & 1131 & & 1113 & \\
$\mathrm{M}+\mathrm{H}$ & 1261 & & 1243 & \\
$\mathrm{M}+\mathrm{H}$ & 1226 & & & \\
$-\mathrm{NH}$ & & & & \\
$-\mathrm{H}_{2} \mathrm{O}$ & & & & \\
\hline
\end{tabular}

Suca-Chr-Ala-AcOHOrn-Gly-(a)Thr-(a)Thr-Gln-Gly-SercOHOrn

An isoform with Mala gives $\mathrm{M}+\mathrm{H} 1277$ and $\mathrm{A}_{1} 416$

(Achouak et al. 2000) and a rhizosphere isolate (R1-4) from oilseed rape (Gasser et al. 2009), were analyzed by means of IEF and LC-MS. All these strains produced $\mathrm{PYO}_{\text {thi }}$ indicating that this pyoverdine is typical for $P$. thivervalensis. Sequencing of the almost complete 16S rRNA gene and partial gyrB and rpoD genes and subsequent phylogenetic analysis with the type strains of the $P$. corrugata subgroup (Mulet et al. 2010) confirmed for all strains, except strain R1-4, their identification as $P$. thivervalensis (Fig. 1).

Screening of an in house IEF data set of pyoverdine samples of a large collection of more than 450 strains revealed an additional strain, the endophyte $P$. brassicacearum BGCR2-9(1) from Solanum nigrum (Long et al. 2008), with the same IEF profile. LC-MS analysis confirmed that this strain also produces $\mathrm{PYO}_{\text {thi }}$. P. brassicacearum BGCR2-9(1) clusters with strain $P$. thivervalensis $\mathrm{R} 1-4$. These results indicate that the ability to produce $\mathrm{PYO}_{\text {thi }}$ is specific for $P$. thivervalensis and a closely related species represented by $P$. brassicacearum BGCR2-9(1) and $P$. thivervalensis $\mathrm{R} 1-4$.

$\mathrm{PYO}_{\text {thi }}$ is structurally almost identical to the pyoverdine of $P$. costantinii $\left(\mathrm{PYO}_{\mathrm{cos}}\right)$ (Fernández et al. 2001) (previously P. tolaasii-like isolate), the first amino acid of the peptide chain of the pyoverdine of $P$. costantinii is serine instead of alanine which gives mass differences of 16 for the $\mathrm{B}$-series (Table 3). The structural similarity is reflected in the IEF profile of both pyoverdines (Fig. 2) which are highly similar. Pyoverdine-mediated ${ }^{59} \mathrm{Fe}$-uptake showed that $\mathrm{PYO}_{\text {cos }}$ was taken up at similar levels $(95 \%$, value

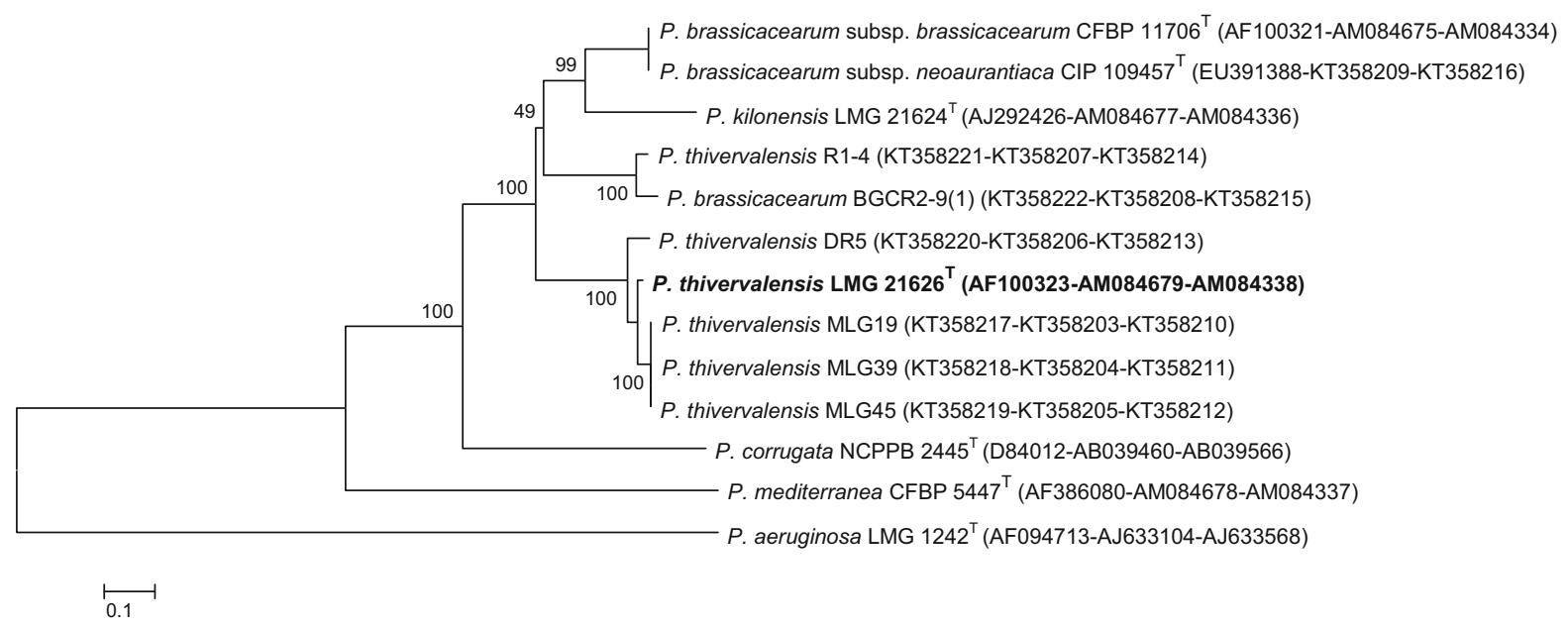

Fig. 1 Neighbor-joining tree based on concatenated almost complete $16 \mathrm{~S}$ rRNA gene sequence and partial gyrB and $r p o D$ gene sequences showing the position of $P$. thivervalensis strains LMG $21626^{\mathrm{T}}$ (in bold), DR5, MLG19, MLG39 and MLG45. Distance matrices were calculated by the Jukes-Cantor method.
Pseudomonas aeruginosa was used as outgroup. The bar indicates sequence divergence. Bootstrap values are indicated at branch points. Genbank accession numbers are given in parentheses 
Fig. 2 Isolectrofocusing patterns of $\mathrm{PYO}_{\text {thi }}$ produced by $P$. thivervalensis $\mathrm{LMG}$ $21626^{\mathrm{T}}(1)$ and pyoverdine produced by $P$. costantinii LMG $22119^{\mathrm{T}}$ (2)

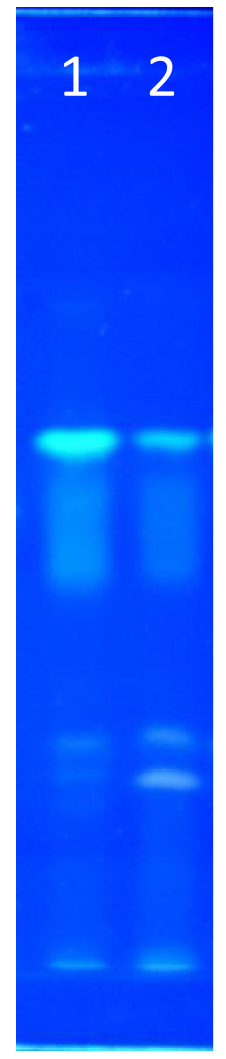

is expressed in percentage of incorporation compared to the homologous system) as $\mathrm{PYO}_{\text {thi }}$ by $P$. thivervalensis wild type strain.

A search of the draft genome sequence of $P$. thivervalensis $\mathrm{LMG} 21626^{\mathrm{T}}$ revealed 25 genes involved in pyoverdine-mediated iron acquisition, transport and regulation which are distributed across three different loci of the genome. Based on in silico analysis of the 3 non-ribosomal peptide synthetases (NRPS) genes (APS14_17615-APS14_17630) (Fig. 3) a nine amino acid long peptide backbone was predicted. As observed for other Pseudomonas species, the chromophore NRPS gene $p v d L$ (APS14_09630) is located at a separate locus (generally together with one enzyme involved of the modification of the peptide chain, and the sigma factor regulator PvdS) while the receptor gene $f p v A$ (APS14_17610) is found at the same locus as the peptide chain biosynthesis genes (Moon et al. 2008). Deletion of $p v d L$ in the mutant $21626^{\mathrm{T}} \Delta \mathrm{pvdL}$ led to complete loss of pyoverdine production as confirmed by loss of fluorescence and loss of the pyoverdine pics in HPLC chromatogram. The pyoverdine-negative mutant was unable to grow on CAA supplemented with the strong iron chelator EDDHA.

P. thivervalensis LMG $21626^{\mathrm{T}}$ produces the secondary siderophore histicorrugatin

The pyoverdine-negative mutant $21626^{\mathrm{T}} \Delta$ pvdL was still able to decolorize chrome azurol $\mathrm{S}$, a large halo was observed after $48 \mathrm{~h}$, suggesting the production of a second siderophore. The halo observed for the $21626^{\mathrm{T}} \Delta$ pvdL mutant is slightly reduced in comparison with the halo of the wild type.

The CAS-positive fraction of the pyoverdine-negative mutant $21626^{\mathrm{T}} \Delta$ pvdL was collected and purified by preparative HPLC. A siderophore, designated histicorrugatin, structurally related to corrugatin and ornicorrugatin was isolated. The mass of the $[\mathrm{M}+\mathrm{H}]^{+}$ion was found to be 1034.5016 corresponding to a molecular formula of $\mathrm{C}_{43} \mathrm{H}_{68} \mathrm{~N}_{15} \mathrm{O}_{15}$ (calc'd. 1034.5018). The mass difference relative to ornicorrugatin $2\left([\mathrm{M}+\mathrm{H}]^{+}\right.$1012) of 22 Da suggests that one of the $\beta$-hydroxyaspartic acid (OHAsp) units of the latter is replaced by $\beta$-hydroxyhistidine (OHHis). The lower mass region up to B3 $(\mathrm{m} / \mathrm{z}, 476)$ corresponds to that of ornicorrugatin (see discussion Matthijs et al. 2008) indicating identical partial structures of the two compounds up to the third $\mathrm{N}$-terminal amino acid (Orn)—except for $m / z 485$ for 1 corresponding to $m / z, 463$ in the spectrum of 2 . This ion represents $\mathrm{Y}^{\prime \prime}{ }_{5}$ after the loss of $74 \mathrm{Da}$ (Supplementary Fig S1, loss of the side chain of OHAsp) from $\mathrm{m} / \mathrm{z}$ 559, a mass increment of $22 \mathrm{Da}$ in agreement with the exchange of one OHAsp by OHHis in the C-terminal part.

In the upper mass range besides $[\mathrm{M}+\mathrm{H}]^{+}(\mathrm{m} / \mathrm{z}$ 1034) elimination of the side chain of OHAsp (-74 Da, $\mathrm{m} / \mathrm{z} 960)$, of OHHis (-96 Da, $\mathrm{m} / \mathrm{z}$ 938) and of both $(-170 \mathrm{Da}, \mathrm{m} / \mathrm{z} 864)$ - see Supplementary Fig $\mathrm{S} 1$-is observed. All these ions are accompanied by the loss of one and two molecules of $\mathrm{H}_{2} \mathrm{O}$. Ions indicating the combined loss of $\mathrm{H}_{2} \mathrm{O}$ and $\mathrm{CO}_{2}(62 \mathrm{Da})$ from various precursors can be seen, viz. $\mathrm{m} / \mathrm{z}, 972$ from 1034,876 from 938 , and the most pronounced one at $\mathrm{m} / \mathrm{z} 802$ arising from $\mathrm{m} / \mathrm{z}, 864$. Of importance for the localization of the new OHHis unit (exchange of the first or third OHAsp starting from the C-terminus) is the ion $m / z 711$. It is shifted to $m / z 697$ for corrugatin and it is observed also at $\mathrm{m} / \mathrm{z}, 711$ for ornicorrugatin. 


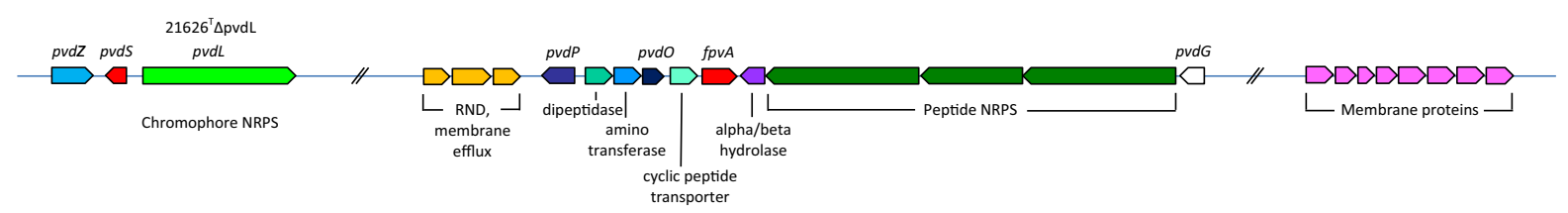

Fig. 3 The organization of the pyoverdine biosynthetic uptake and regulation gene cluster of P. thivervalensis LMG $21626^{\mathrm{T}}$. Double vertical lines represent intervening DNA

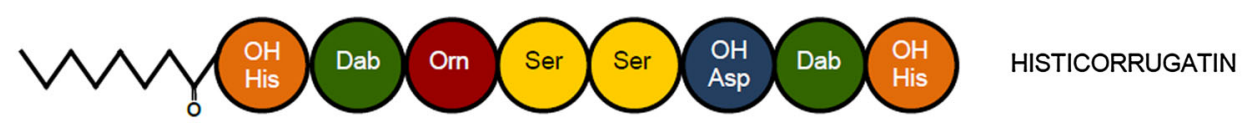

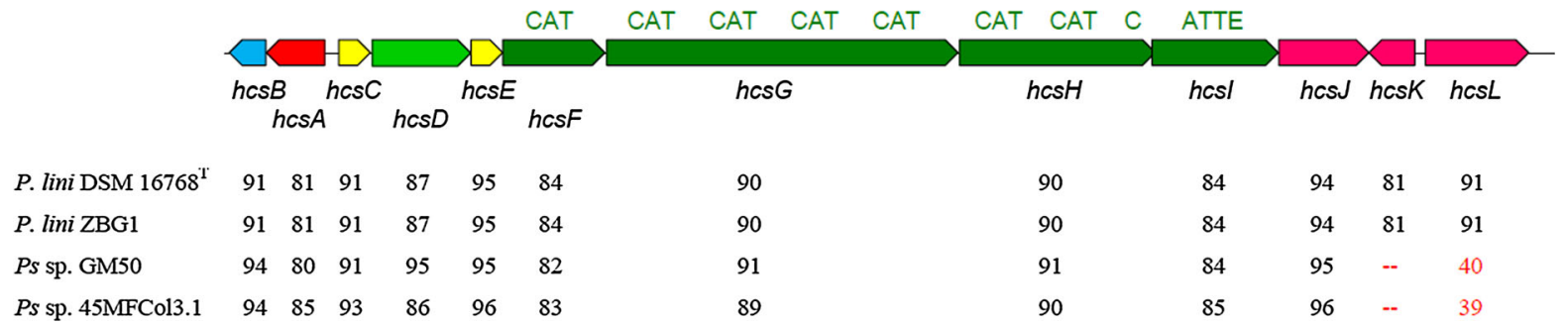

Fig. 4 A schematic presentation of the structure of histicorrugatin and the histicorrugatin biosynthetic and uptake gene cluster of $P$. thivervalensis LMG $21626^{\mathrm{T}}$. The organization of the modules and domains in these four proteins is shown above the arrows. Below the gene cluster the similarities of the

Therefore it contains the N-terminal parts of the molecules. It stems from the combined elimination (loss of $170 \mathrm{Da}$ ) of the side chains of OHAsp and OHHis from $\mathrm{m} / \mathrm{z} 881$ (this ion is more pronounced in the MS2-spectrum) which in turn is formed by the loss of the respective C-terminal amino acid with backtransfer of the $\mathrm{OH}$ group, in this case by the loss of 153 Da corresponding to OHHis (Fuchs and Budzikiewicz 2001). Kept in the solution obtained by elution of the sample from the column during purification histicorrugatin $\mathbf{1}$ decomposes after some time by elimination of the OHHis residue (96 Da), as observed in the mass spectra. The mass of the $[\mathrm{M}+\mathrm{H}]^{+}$ion of the resulting species $\mathrm{m} / \mathrm{z} 938.4692$ corresponds to $\mathrm{C}_{39} \mathrm{H}_{64} \mathrm{~N}_{13} \mathrm{O}_{14}$ (calc'd. 938.4695). Its mass spectrometric fragmentation corresponds to that discussed for the parent compound 1. Of importance is again $m / z 711$, here due to the loss of the OHAsp side chain only from $\mathrm{m} / \mathrm{z} 785$ which is formed by the elimination of $153 \mathrm{Da}$ (see above).

A gene cluster for histicorrugatin biosynthesis and transport was found by searching the $P$. thivervalensis proteins of $P$. thivervalensis LMG $21626^{\mathrm{T}}$ with translated gene products of Pseudomonas sp. GM50, Pseudomonas sp. 45MFCol3.1, $P$. lini LMG $21625^{\mathrm{T}}$ and $P$. lini ZBG1 are shown. Similarities below $50 \%$ are shown in red. The locus tags of the proteins are given in Supplementary Table S1

genome and BLAST homology. The gene cluster resides on a $42.1 \mathrm{~kb}$ fragment and includes 12 open reading frames (ORFs). The predicted function for each ORF was assigned by comparing the translated product with known proteins in public databases. Four non-ribosomal peptide synthetases (NRPS), designated HcsF, HcsG, HcsH, and HcsI (APS14_13800APS14_13815) assemble the 8-residue histicorrugatin peptide backbone. The organization of the modules and domains in these four proteins is shown in Fig. 4. These eight modules adhere to the colinearity rule, specifying a colinear relationship between number and type of amino acids and the number and sequence of modules. In addition a thioesterase (TE) domain which catalyzes the release of NRPS product was found in the last protein HcsI (Fig. 4).

Several non-proteinogenic amino acids were found in the peptide chain of histicorrugatin (Fig. 4). There are 2 L-Dab (2,4-diaminobutanoic acid) residues. These arise probably from HcsB (APS14_13840), a diaminobutyrate-2-oxoglutarate transaminase that catalyzes the reversible conversion of L-aspartate 
4-semialdehyde + L-glutamate to L-2,4-diaminobutanoate +2 -oxoglutarate. In addition one ornithine residue was found in the peptide chain of histicorrugatin (Fig. 4). Genes directing the synthesis of this amino acid were not expected since ornithine is normally found in the bacterial cell as intermediate in arginine metabolism.

Several hydroxylated amino acids were found in the histicorrugatin backbone, at the first and last position an OHHis and at the sixth position an OHAsp (Fig. 4). These residues are most likely hydroxylated by the SyrP proteins HcsC (APS14_13830) and HcsE (APS14_13820) (Singh et al. 2008). Both SyrP proteins showed an identity of $43 \%$ in a 294 residues overlap. At the $\mathrm{N}$-terminal of the peptide chain of histicorrugatin a fatty acid is found (Fig. 4). HcsD (APS14_13825), similar to acyl-CoA synthetases (AMP-forming)/AMP-acid ligases, is predicted to act on the octanoid acid to synthesize an acyl-CoA derivate. The role of the gene cluster in histicorrugatin biosynthesis was confirmed through the construction of deletion mutants, deletion of 2 biosynthetic genes ( hcsEF) in $21626^{\mathrm{T}} \Delta \mathrm{hcsEF}$ and $21626^{\mathrm{T}} \Delta$ pvdL $\Delta$ hcsEF resulted in complete loss of histicorrugatin production. Export of the siderophore from the cell is likely to involve HcsJ, HcsK and HcsL (APS14_13785-13795) predicted to function as components of $\mathrm{ABC}$ transporters (Fig. 4). Uptake of histicorrugatin probably occurs through the TonB-dependent receptor HcsA (APS14_13835) (Fig. 4). Deletion of the receptor in mutant $21626^{\mathrm{T}} \Delta$ hcsA resulted in a decreased production of histicorrugatin.

The double mutant $21626^{\mathrm{T}} \Delta$ pvdL $\Delta$ hcsEF, unable to produce $\mathrm{PYO}_{\text {thi }}$ and histicorrugatin, showed a weak, diffuse CAS discoloration activity. If there is an alternative third iron uptake system it should have a rather low activity for iron.

By LC-MS analysis histicorrugatin was also detected in the $P$. thivervalensis strains DR5, MLG19, MLG39 and MLG45. Histicorrugatin was not detected in the closely related strain $P$. brassicacearum BGCR2-9(1), but the siderophore ornicorrugatin was found in its supernatant. By searching public databases a putative histicorrugatin biosynthetic and uptake gene cluster was found in Pseudomonas lini DSM $16768^{\mathrm{T}}$, Pseudomonas lini ZBG1, Pseudomonas sp. 45MFCol3.1 and Pseudomonas sp. GM50 (Fig. 4). Histicorrugatin was indeed detected in the culture supernatant of $P$. lini LMG $21625^{\mathrm{T}}$, but under the conditions used, histicorrugatin was not detected in the supernatant of strain GM50 (nor ornicorrugatin or corrugatin). The other 2 strains were not available and their siderophores produced could therefore not be verified.

In Pseudomonas sp. GM50 and 45MFCol3.1 the last two genes, a putative siderophore-iron reductase and a gene involved in transport of histicorrugatin, showed respectively no and a low similarity at the amino acid level to the translated genes $h c s K$ and $h c s L$ of $P$. thivervalensis LMG $21626^{\mathrm{T}}$ (Fig. 4). But they were highly similar to each other (89 and $93 \%$ identity at amino acid level, respectively) indicating that they have the same origin. Blast analysis showed only low levels of identity of these two genes of GM50 and 45MFCol3.1 with predominantly non Pseudomonas strains so it is not clear as where these genes are coming from. The presence of these 'atypical' genes might explain why no histicorrugatin production was observed in Pseudomonas sp. GM50. Nevertheless, these results show that histicorrugatin production is probably not rare and not limited to $P$. thivervalensis strains.

Utilization of exogenous pyoverdines by $P$. thivervalensis LMG $21626^{\mathrm{T}}$ and $P$. brassicacearum subsp. brassicacearum NFM 421

Pseudomonas strains produce a limited number of siderophores but they are able to use many exogenous siderophores due to the presence of a multitude of receptors in their genome (Cornelis and Matthijs 2002). In addition to the cognate pyoverdine receptor FpvA and the histicorrugatin receptor an additional 23 TonB-dependent receptors were found in the $\mathrm{LMG}$ $21626^{\mathrm{T}}$ proteome. For four of these receptors gene expression is probably controlled by ECF $\sigma$ factors as indicated by the presence of extracytoplasmic sigma factors and transmembrane anti- $\sigma$ factors adjacent to the receptor (Table 5). Based on Blast analysis a putative function could be attributed to five TonB dependent receptors, responsible for the uptake of ferrioxamine B, copper, heme, coprogen and rhodotorulic acid, and ferrichrome, respectively (Table 5).

Pseudomonas strains are also able to utilize pyoverdine from other fluorescent pseudomonads (Matthijs et al. 2009; Hartney et al. 2011; Ye et al. 2014a). To estimate the diversity of exogenous pyoverdines that may be utilized by $P$. thivervalensis 
Table 5 TonB-dependent receptors found in the genome of $P$. thivervalensis LMG $21626^{\mathrm{T}}$, their putative role based on Blast analysis, presence of ECF sigma factor and the level of identity at amino acid level of their closest homologues in $P$. brassicacearum subsp. brassicacearum NFM 421

\begin{tabular}{|c|c|c|c|c|}
\hline $\begin{array}{l}\text { TonB-dependent receptors of LMG } \\
21626^{\mathrm{T}}\end{array}$ & Residues & Function based on blast hit & $\begin{array}{l}\text { ECF } \\
\text { sigma }\end{array}$ & $\begin{array}{l}\text { Level of identity (aa) to NFM } \\
421\end{array}$ \\
\hline APS14_00155 & 834 & Ferrioxamine B & Yes & $97 \%$ to PSEBR_a193 \\
\hline APS14_02400 & 708 & Copper & & $98 \%$ to PSEBR_a609 \\
\hline APS14_04030 & 782 & & & $94 \%$ to PSEBR_a901 \\
\hline APS14_05530 & 864 & Heme & Yes & $95 \%$ to PSEBR_a1204 \\
\hline APS14_06930 & 713 & & & $97 \%$ to PSEBR_a3192 \\
\hline APS14_07200 & 210 & & & $89 \%$ to PSEBR_a3239 \\
\hline APS14_07855 & 796 & & Yes & - \\
\hline APS14_11280 & 715 & & & - \\
\hline APS14_11285 & 683 & & & - \\
\hline APS14_11650 & 807 & & & $95 \%$ to PSEBR_a2949 \\
\hline APS14_11715 & 842 & & & $97 \%$ to PSEBR_a2962 \\
\hline APS14_12340 & 667 & & & - \\
\hline APS14_12450 & 716 & & & - \\
\hline APS14_13415 & 803 & & & - \\
\hline APS14_13435 & 741 & & & - \\
\hline APS14_13835 & 687 & Histicorrugatin & & $93 \%$ to PSEBR_a2396 \\
\hline APS14_16155 & 722 & FpvA & & $94 \%$ to PSEBR_a3481 \\
\hline APS14_16900 & 825 & $\begin{array}{l}\text { Coprogen and rhodotorulic } \\
\text { acid }\end{array}$ & & $95 \%$ to PSEBR_a1921 \\
\hline APS14_17610 & 816 & FpvA PYO thi & & $38 \%$ to PSEBR_a3917 \\
\hline APS14_18690 & 707 & & & $97 \%$ to PSEBR_a4120 \\
\hline APS14_22195 & 701 & & & $95 \%$ to PSEBR_a4729 \\
\hline APS14_23650 & 707 & & & $95 \%$ to PSEBR_a2765 \\
\hline APS14_24450 & 626 & & & $95 \%$ to PSEBR_a5030 \\
\hline APS14_25320 & 812 & Ferrichrome & Yes & $95 \%$ to PSEBR_a5195 \\
\hline APS14_28280 & 730 & & & - \\
\hline
\end{tabular}

LMG $21626^{\mathrm{T}}$, pyoverdines were purified from 31 different Pseudomonas strains and isolates (Table 3), which had been shown to each produce a unique siderotype profile (Meyer et al. 2008; Matthijs et al. 2009). The pyoverdines were supplied to the pyoverdine and histicorrugatin-deficient mutant $21626^{\mathrm{T}-}$ $\Delta$ pvdL $\Delta$ hcsEF that had been overlaid as a dilute suspension onto CAA medium containing 2,2-dipyridyl. Growth was clearly restored by provision of some of the purified pyoverdines, including the cognate pyoverdine $\mathrm{PYO}_{\text {thi }}$ (Table 3). Out of the other 30 pyoverdines tested, 13 were able to stimulate growth (Table 3), these included the pyoverdine of $P$. agarici $\mathrm{LMG}$ $2112^{\mathrm{T}}$, P. brassicacearum subsp. brassicacearum
NFM 421, P. chlororaphis D-TR133, P. chlororaphis W2Apr9, $P$. costantinii LMG $22119^{\mathrm{T}}, \quad P$. lini W2Aug36, $P$. lurida LMG $21995^{\mathrm{T}}$, $P$. protegens $\mathrm{Pf}-$ 5, P. rhodesiae LMG $17764^{\mathrm{T}}$, P. salomonii $\mathrm{LMG}$ $22120^{\mathrm{T}}$, Pseudomonas sp. W15Apr2, Pseudomonas sp. W15Feb38 and type II pyoverdine of $P$. aeruginosa 7NSK2. These results show that $P$. thivervalensis can utilize a diverse set of pyoverdines as iron sources. The pyoverdine of $P$. brassicacearum subsp. brassicacearum NFM 421 was not able to fully restore growth in the conditions of the assay. In addition it has been observed that when the growth stimulation assay was repeated out in the presence of the strong iron chelator EDDHA (instead of 2,2-dipyridyl) 
pyoverdine of NFM 421 cannot stimulate at all the growth of a pyoverdine-negative mutant of $P$. thivervalensis. Pyoverdine-mediated ${ }^{59} \mathrm{Fe}$-uptake showed that the pyoverdine of NFM 421 was taken up at low levels ( $35 \%$, value is expressed in percentage of incorporation compared to the homologous system) by $P$. thivervalensis wild type strain.

Strain LMG $21626^{\mathrm{T}}$ was not able to utilize type I pyoverdine produced by $P$. aeruginosa PAO1 and pyoverdines of strains of the $P$. putida group (Mulet et al. 2010) including P. entomophila $\mathrm{L}^{4} 8^{\mathrm{T}}, P$. putida BTP2, P. putida KT2440, P. putida W15Oct28, Pseudomonas sp. W2Jun14 and Pseudomonas sp. W15Oct11 which all produce structurally different pyoverdines. In addition, LMG $21626^{\mathrm{T}}$ was not able to utilize the pyoverdine of $P$. cedrina, $P$. citronellolis, $P$. fluorescens DSM 50106, P. fluorescens LMG 14562, and the type strain of $P$. asplenii, $P$. brenneri, $P$. koreensis, $P$. libanensis and $P$. mosselii.

$P$. thivervalensis is phylogenetically most closely related to $P$. brassicacearum. Therefore it was verified whether their phylogenetic relationship was reflected in the number and type of TonB-dependent receptors and whether there are large differences in their pyoverdine uptake profiles. IEF and LC-MS analysis showed that NFM 421 produces the same pyoverdine as P. putida ATCC 39167 (Uría-Fernández et al. 2003) (Table 3). Sequencing of 16S rRNA of ATCC 39167 revealed that the strain received as ATCC 39167 is not a $P$. putida strain, but belongs to the $P$. fluorescens group and is closely related to $P$. brassicacearum. Their 16S rRNAs (1278 bp) show a $99.7 \%$ identity at nucleotide level.

Seventeen TonB-dependent receptors of NFM 421 were extracted from its genome and a phylogenetic tree was constructed with the 25 TonB-dependent receptors of LMG $21626^{\mathrm{T}}$. Interestingly, almost all the receptors of NFM 421 clustered with a homologue of P. thivervalensis (Fig. 5). The TonB-receptors showed very high identity levels at the amino acid level, values between 89 and $98 \%$ were observed (Table 5). In fact only the cognate pyoverdine receptor of NFM 421 , which showed only an identity of $38 \%$ with the FpvA receptor of $P$. thivervalensis (Table 5), did not cluster with a homologue.

The histicorrugatin receptor of $P$. thivervalensis showed an identity of $93 \%$ to PSEBR_a2396 of NFM 421. Histicorrugatin was not detected in the culture supernatant of NFM 421 but the analogue ornicorrugatin was found. Ornicorrugatin is produced by the gene cluster PSEBR_a2386-PSEBR_a2397 of NFM 421, Tn5 mutants in the nrps genes PSEBR_a2390 and PSEBR_a2391 lead to a complete loss of ornicorrugatin production (Matthijs S., unpublished results).

To compare the diversity of exogenous pyoverdines that may be utilized by both strains, growth stimulation assays were repeated as described above with the pyoverdine-negative mutant NFM421-4D1 of $P$. brassicacearum subsp. brassicacearum NFM 421. The pyoverdine utilization profiles of both strains are almost identical (Table 3). In contrast to the pyoverdine of NFM 421 which was not able to stimulate growth of $P$. thivervalensis very well, clear growth stimulation was observed of $\mathrm{PYO}_{\mathrm{thi}}$ for $P$. brassicacearum. A difference in the utilization profiles of both strains was observed for the pyoverdine of $P$. citronellolis LMG $18378^{\mathrm{T}}$ and P. fluorescens Pf0-1, these pyoverdines were only able to crossfeed $P$. brassicacearum (Table 3).

\section{Discussion}

$P$. thivervalensis sp. are typically plant-associated bacteria, they have been isolated as endophyte from Solanum nigrum (Long et al. 2008) and from Arabidopsis thaliana and Brassica napus roots (Achouak et al. 2000). This work shows that they produce the high affinity siderophore pyoverdine $\left(\mathrm{PYO}_{\text {thi }}\right)$ and the lipopeptidic siderophore histicorrugatin under iron limiting conditions to fulfill their need for iron. Iron is an essential element; it is a constituent of enzymes with critical roles in metabolism of hydrogen, oxygen or nitrogen, electron transfer, RNA synthesis and dissolution of reactive oxygen intermediates (Braun 1997). Acquisition of iron is complicated by the inherently low solubility of ferric iron, possible adsorption of $\mathrm{Fe}^{3+}$ on to colloids and precipitation of iron with other ions result in even lower iron concentrations in soil.

The production of iron-chelating siderophores by bacteria can be beneficial for the plant, because they can significantly increase the solubility of iron (Lemanceau et al. 2009). Nutritional competition for iron by the production of siderophores has been extensively studied as a mechanism of biological control. The plant growth-promoting effect of some 


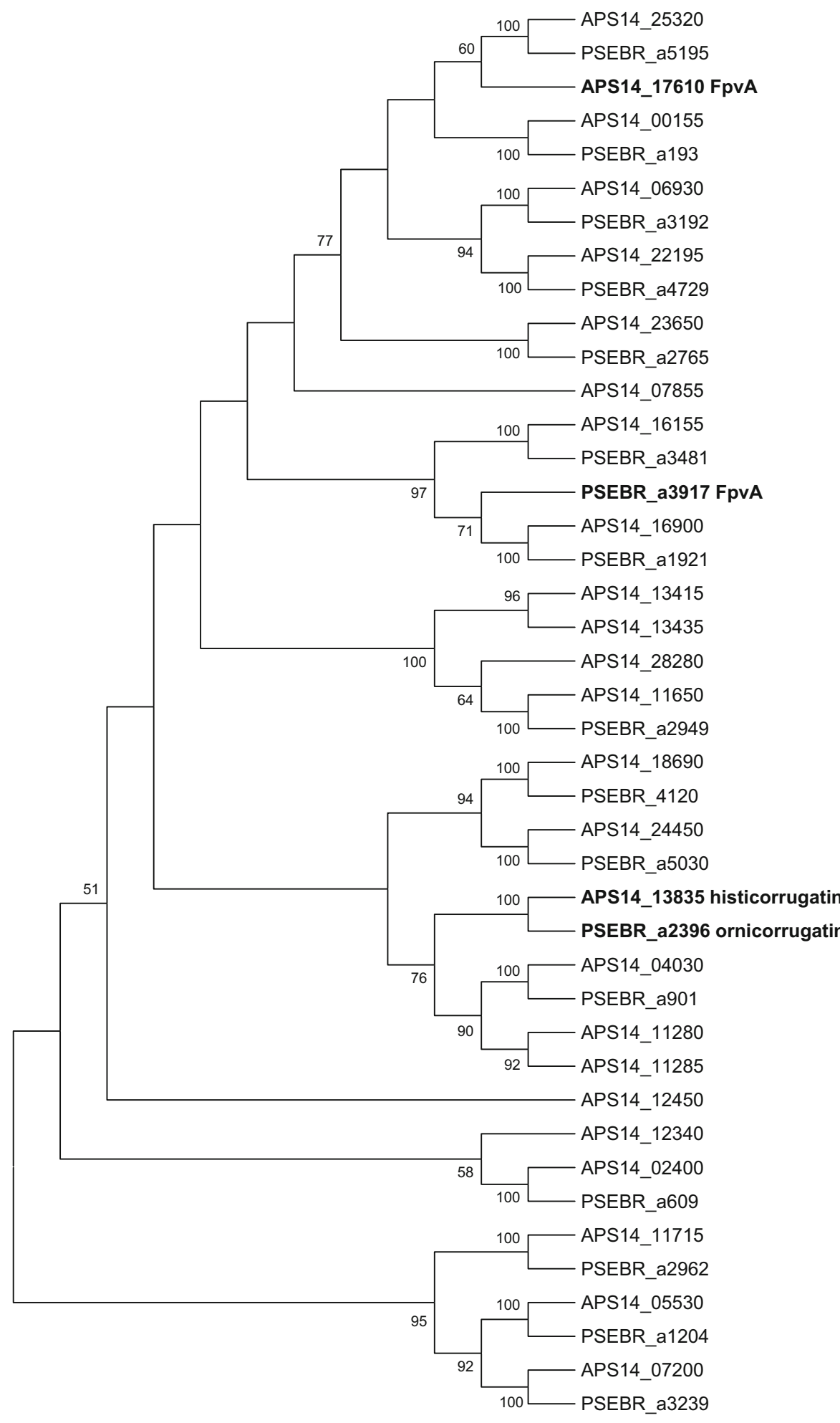

Fig. 5 Phylogenetic relationships among amino acid sequences of all the putative TonB-dependent receptors of $P$. brassicacearum NFM 421 and $P$. thivervalensis LMG $21626^{\mathrm{T}}$. The locus tag of each receptor is indicated on the tree. The tree was constructed using the $\mathrm{NJ}$ method. Numbers at nodes represent levels (\%) of bootstrap support from 500 resampled datasets 
fluorescent pseudomonads is thought to be in part due to siderophores, including pyoverdine, pyochelin and salicylic acid, that sequester iron in a form unavailable to deleterious micro-organisms in the rhizosphere, thereby preventing the pathogens' access to the already limited pool of soluble iron in the rhizosphere if the latter do not possess more efficient iron uptake systems (Kloepper et al. 1980; Höfte et al. 1991; Loper and Henkels 1997; Duijff et al. 1999). In addition, it has been observed that siderophores produced by fluorescent pseudomonads can trigger defense responses in the host (Maurhofer et al. 1994; Leeman et al. 1996; Bakker et al. 2007; De Vleesschauwer and Höfte, 2009).

Another trait, besides the ability to produce high affinity siderophore(s), which is important when microorganisms are competing for iron, is the ability to utilise iron complexes of a variety of different siderophores produced by other microorganisms, including fungi and bacteria (Poole et al. 1990; Jurkevitch et al. 1992; Raaijmakers et al. 1995). This "siderophore piracy" has two obvious advantages, the microorganism does not have to use metabolic energy for the synthesis of iron chelators, and by stealing the siderophore of other microorganisms it deprives these organisms of iron. It has been shown that $P$. fluorescens BBc6R8, in the presence of a coelichelin and desferrioxamines producing Streptomyces strain, did not produce pyoverdine but relied on utilisation of the siderophores produced by the Streptomyces strain (Galet et al. 2015). The capacity to utilise exogenous siderophores varies between Pseudomonas species and probably reflects the importance of iron competition in the natural habitat of the bacteria. Based on in silico analysis the receptors for the uptake of the siderophores ferrioxamine $\mathrm{B}$, coprogen, rhodotorulic acid and ferrichrome could be attributed to $P$. thivervalensis $\mathrm{LMG} 21626^{\mathrm{T}}$.

Strain LMG $21626^{\mathrm{T}}$ has in total 25 TonB-dependent receptors, eigth more than its phylogenetic neighbor $P$. brassicacearum. These numbers are on the lower side, especially for $P$. brassicacearum subsp. brassicacearum NFM 421 which has the lowest number of TonB-dependent receptors reported until now, but is in the same range as the phytopathogen $P$. syringae for which 19 (B728a) to 25 (DC3000) TonBdependent receptors are found (Cornelis and Bodilis 2009). In contrast, the total number of genes coding for TonB-dependent receptors in the plant-associated $P$. fluorescens strains A506, SBW25 and $P$. protegens $\mathrm{Pf}-$ 5 are respectively 34, 37 and 45 (Hartney et al. 2011). The highest number of TonB-dependent receptors has been found in P. putida W15Oct28 isolated from a small river (Matthijs et al. 2013), which has the amazing number of 56 genes coding for TonBdependent receptors (Ye et al. 2014b). But what is intriguing when comparing the type of TonB dependent-receptors between $P$. thivervalensis and $P$. brassicacearum is that NFM 421 has the same pool of TonB-dependent receptors, except for the cognate FpvA receptor, as $P$. thivervalensis. $P$. thivervalensis has an additional 8 receptors, giving this strain probably a competitive advantage over $P$. brassicacearum. It would be interesting to study which type of compounds can be taken up by these additional TonB-dependent receptors.

Two pyoverdine receptors are found in $P$. thivervalensis LMG $21626^{\mathrm{T}}$ and $P$. brassicacearum subsp. brassicacearum NFM 421, their cognate FpvA receptor and a putative second pyoverdine receptor (APS14_16155 and PSEBR_a3481, respectively). These receptors do not belong to the core genome, but to the accessory genome (Cornelis and Bodilis 2009). Pyoverdine growth stimulation assays showed that $P$. thivervalensis and $P$. brassicacearum are able to utilize respectively 13 and 15 structurally distinct pyoverdines produced by other Pseudomonas sp. out of 31 pyoverdines tested. This number is roughly comparable to the 17 pyoverdines $P$. protegens $\mathrm{Pf}-5$ is able to utilize (Hartney et al. 2011). For P. fluorescens ATCC 17400 this was 20 out of 28 pyoverdines tested (Ye et al. 2014a) and for P. entomophila 16 out of 24 (Matthijs et al. 2009). Since sometimes different pyoverdines have been tested for these strains these data cannot be directly compared but they do indicate that many pyoverdines can be utilized by $P$. thivervalensis.

Despite the fact that the cognate FvpA receptors of $P$. thivervalensis and P. brassicacearum did not show large sequence similarities and did not cluster together in the phylogenetic tree of TonB-dependent receptors (Fig. 5), the pyoverdine utilisation profiles of $P$. thivervalensis and $P$. brassicacearum are almost identical. The observed differences in the uptake profiles of both strains, whereby NFM 421 can take up 2 additional pyoverdines, can probably be attributed to

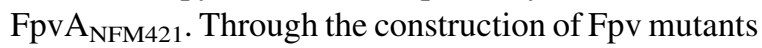
the specificity and the level of redundancy of each 
receptor can be further studied. The similarities in their uptake profile might reflect, besides their genetic similarities, their biological origin. Both strains were isolated in the same study, but from different plants and geographic environments; LMG $21626^{\mathrm{T}}$ was isolated from Brassica napus and NFM 421 from Arabidopsis thaliana (Achouak et al. 2000). But in the latter study both $P$. thivervalensis and $P$. brassicacearum strains have been isolated from $B$. napus and A. thaliana (Achouak et al. 2000), which indicate that they are probably able to colonize the same host plant.

Acknowledgments The authors are indebted to Pelletier Dale, Baldwin Ian-Thomas and Gasser Ilona for generous gift of strains.

\section{References}

Achouak W, Sutra L, Heulin T, Meyer J-M, Fromin N, Degraeve S, Christen R, Gardan L (2000) Pseudomonas brassicacearum sp. nov. and Pseudomonas thivervalensis sp. nov., two root-associated bacteria isolated from Brassica napus and Arabidopsis thaliana. Int J Syst Evol Microbiol 50:9-18

Barelmann I, Fernandez DU, Budzikiewicz H, Meyer JM (2003) The pyoverdine from Pseudomonas chlororaphis D-TR133 showing mutual acceptance with the pyoverdine of Pseudomonas fluorescens CHA0. BioMetals 16:263-270

Bakker PAHM, Pieterse CMJ, van Loon LC (2007) Induced systemic resistance by fluorescent Pseudomonas spp. Phytopathol 97:239-243

Braun V (1997) Avoidance of iron toxicity through regulation of bacterial iron transport. Biol Chem 378:779-786

Briskot G, Taraz K, Budzikiewicz H (1989) Pyoverdine-type siderophores from Pseudomonas aeruginosa. Liebigs Ann Chem 1989:375-384

Brown SD, Utturkar SM, Klingeman DM, Johnson CM, Martin SL, Land ML, Lu T-YS, Schadt CW, Doktycz MJ, Pelletier DA (2012) Twenty-one genome sequences from Pseudomonas species and 19 genome sequences from diverse bacteria isolated from the rhizosphere and endosphere of Populus deltoids. J Bacteriol 194:5991-5993

Budzikiewicz H (1997) Siderophores of fluorescent pseudomonads. Z Naturforsch 52:713-720

Budzikiewicz H (2004) Siderophores of the Pseudomonadaceae sensu stricto (fluorescent and non-fluorescent Pseudomonas spp.). Prog Chem Org Nat Prod 87:81-237

Budzikiewicz H, Schröder H, Taraz K (1992) Zur Biogenese der Pseudomonas-siderophore: der Nachweis analoger Strukturen eines Pyoverdin-Desferribactin-Paares. Z Naturforsch C 47:26-32

Budzikiewicz H, Schäfer M, Fernández DU, Matthijs S, Cornelis P (2007) Characterization of the chromophore of pyoverdins and related siderophores by electrospray tandem mass spectrometry. Biometals 20:135-144
Cheng X, de Bruijn I, van der Voort M, Loper JE, Raaijmakers JM (2013) The Gac regulon of Pseudomonas fluorescens SBW25. Environ Microbiol Rep 5:608-619

Cornelis P, Bodilis J (2009) A survey of TonB-dependent receptors in fluorescent pseudomonads. Environ Microbiol Rep 1:256-262

Cornelis P, Matthijs S (2002) Diversity of siderophore-mediated iron uptake systems in fluorescent pseudomonads: not only pyoverdines. Environ Microbiol 4:787-798

Cox CD, Graham R (1979) Isolation of an iron-binding compound from Pseudomonas aeruginosa. J Bacteriol 137: 357-364

De Vleesschauwer D, Höfte M (2009) Rhizobacteria-induced systemic resistance. Plant Innate Immunity 51:223-281

Delorme S, Lemanceau P, Christen R, Corberand T, Meyer JM, Gardan L (2002) Pseudomonas lini sp. nov., a novel species from bulk and rhizospheric soils. Int $\mathrm{J}$ Syst Evol Microbiol 52:513-523

Dennis JJ, Zylstra GJ (1998) Plasposons: modular self-cloning minitransposon derivatives for rapid genetic analysis of gram-negative bacterial genomes. Appl Environ Microbiol 64:2710-2715

Duijff BJ, Recorbet G, Bakker PAHM, Loper JE, Lemanceau P (1999) Microbial antagonism at the root level is involved in the suppression of fusarium wilt by the combination of nonpathogenic Fusarium oxysporum Fo47 and Pseudomonas putida WCS358. Phytopathol 89:1073-1079

Edwards U, Rogall T, Blöcker H, Emde M, Böttger EC (1989) Isolation and direct complete nucleotide determination of entire genes, characterization of a gene coding for $16 \mathrm{~S}$ ribosomal RNA. Nucl Acids Res 17:7843-7853

Fernández DU, Fuchs R, Taraz K, Budzikiewicz H, Munsch P, Meyer J-M (2001) Structure of a pyoverdine produced by a Pseudomonas tolaasii-like isolate. Biometals 14:81-84

Fuchs R, Budzikiewicz H (2001) Rearrangement reactions in the electrospray ionization mass spectra of pyoverdins. Int $\mathrm{J}$ Mass Spectrom 201(211):603-612

Galet J, Deveau A, Hôtel L, Frey-Klett P, Leblond P, Aigle B (2015) Pseudomonas fluorescens pirates both ferrioxamine and ferri-coelichelin siderophores from Streptomyces ambofaciens. Appl Environ Microbiol 81:3132-3141

Gasser I, Müller H, Berg G (2009) Ecology and characterization of polyhydroxyalkanoate-producing microorganisms on and in plants. FEMS Microbiol Ecol 70:142-150

Hartney SL, Mazurier S, Kidarsa TA, Quecine MC, Lemanceau P, Loper JE (2011) TonB-dependent outer-membrane proteins and siderophore utilization in Pseudomonas fluorescens $\mathrm{Pf}-5$. Biometals 24:193-213

Höfte M, Seong KY, Jurkevitch E, Verstraete W (1991) Pyoverdine production by the plant growth beneficial Pseudomonas strain 7NSK2: ecological significance in soil. Plant Soil 130:249-257

Jurkevitch E, Hadar Y, Chen Y (1992) Differential siderophore utilization and iron uptake by soil and rhizosphere bacteria. Appl Environ Microbiol 58:119-124

Kloepper JW, Leong J, Teintze M, Schroth MN (1980) Enhanced plant growth by siderophores produced by plant growth-promoting rhizobacteria. Nature 286:885-886

Leeman M, den Ouden FM, van Pelt JA, Dirkx FPM, Steijl H, Bakker PAHM, Schippers B (1996) Iron availability affects induction of systemic resistance to Fusarium wilt of 
radish Pseudomonas fluorescens. Phytopathology 85: 149-155

Lemanceau P, Expert D, Gaymard F, Bakker P, Briat JF (2009) Role of iron in plant-microbe interactions. Plant Innate Immunity 51:491-549

Long HH, Schmidt DD, Baldwin IT (2008) Native bacterial endophytes promote host growth in a species-specific manner; phytohormone manipulations do not results in common growth responses. PLoS One 3(7):e2702

Loper JE, Henkels MD (1997) Availability of iron to Pseudomonas fluorescens in rhizosphere and bulk soil evaluated with an ice nucleation reporter gene. Appl Environ Microbiol 63:99-105

Matthijs S, Baysse C, Koedam N, Abbaspour Tehrani K, Verheyden L, Budzikiewicz H, Schäfer M, Hoorelbeke B, Meyer J-M, De Greve H, Cornelis P (2004) The Pseudomonas siderophore quinolobactin is synthesized from xanthurenic acid, an intermediate of the kynurenine pathway. Mol Microbiol 52:371-384

Matthijs S, Abbaspour Tehrani K, Laus G, Jackson RW, Cooper RM, Cornelis P (2007) Thioquinolobactin, a Pseudomonas siderophore with antifungal and anti-Pythium activity. Environ Microbiol 9:425-434

Matthijs S, Budzikiewicz H, Schäfer M, Wathelet B, Cornelis P (2008) Ornicorrugatin, a new siderophore from Pseudomonas fluorescens AF76. Z Naturforsch C 63:8-12

Matthijs S, Laus G, Meyer JM, Abbaspour-Tehrani K, Schäfer M, Budzikiewicz H, Cornelis P (2009) Siderophore-mediated iron acquisition in the entomopathogenic bacterium Pseudomonas entomophila. Biometals 22:951-964

Matthijs S, Coorevits A, Gebrekidan TT, Tricot C, Vander Wauven C, Pirnay J-P, De Vos P, Cornelis P (2013) Evaluation of the oprI and oprL genes as molecular markers for the genus Pseudomonas and their use to study the biodiversity of a small Belgian River. Res Microbiol 164:254-261

Maurhofer M, Hase C, Meuwly P, Métraux JP, Défago G (1994) Induction of systemic resistance of tobacco to tobacco necrosis virus by the root-colonizing Pseudomonas fluorescens strain CHA0: influence of the gacA gene and of pyoverdine production. Phytopathol 84:39-146

Mercado-Blanco J, van der Drift KMGM, Olsson PE, ThomasOates JE, van Loon LC, Bakker PAHM (2001) Analysis of the pms $C E A B$ gene cluster involved in the biosynthesis of salicylic acid and the siderophore pseudomonine in the biocontrol strain Pseudomonas fluorescens WCS374. J Bacteriol 183:1909-1920

Meyer J-M, Abdallah MA (1978) The fluorescent pigment of Pseudomonas fluorescens: biosynthesis, purification and physicochemical properties. J Gen Microbiol 107:319-328

Meyer J-M, Geoffroy VA, Baida N, Gardan L, Izard D, Lemanceau P, Achouak W, Palleroni NJ (2002) Siderophore typing, a powerful tool for the identification of fluorescent and nonfluorescent pseudomonads. Appl Environ Microbiol 68:2745-2753

Meyer J-M, Gruffaz C, Raharinosy V, Bezverbnaya I, Schäfer M, Budzikiewicz H (2008) Siderotyping of fluorescent Pseudomonas: molecular mass determination by mass spectrometry as a powerful pyoverdine siderotyping method. Biometals 21:259-271
Moon CD, Zhang XX, Matthijs S, Schäfer M, Budzikiewicz H, Rainey PB (2008) Genomic, genetic and structural analysis of pyoverdine-mediated iron acquisition in the plant growth-promoting bacterium Pseudomonas fluorescens SBW25. BMC Microbiol 8:7

Mulet M, Bennasar A, Lalucat J, García-Valdés E (2009) An $r p o D$-based PCR procedure for the identification of Pseudomonas species and for their detection in environmental samples. Mol Cellul Prob 23:140-147

Mulet M, Lalucat J, García-Valdés E (2010) DNA sequencebased analysis of the Pseudomonas species. Environ Microbiol 12:1513-1530

Ongena M, Jacques P, Thonart P, Gwose I, Fernandez DU, Schäfer M, Budzikiewicz H (2001) The pyoverdin of Pseudomonas fluorescens BTP2, a novel structural type. Tetrahedron Lett 42:5849-5851

Poole K, Young L, Neshat S (1990) Enterobactin-mediated iron transport in Pseudomonas aeruginosa. J Bacteriol 172:6991-6996

Raaijmakers JM, Van Der Sluis I, Koster M, Bakker PAHM, Weisbeek PJ, Schippers B (1995) Utilization of heterologous siderophores and rhizosphere competence of fluorescent Pseudomonas spp. Can J Microbiol 41:126-135

Rausch C, Weber T, Kohlbacher O, Wohlleben W, Huson DH (2005) Specificity prediction of adenylation domains in nonribosomal peptide synthetases (NRPS) using transductive support vector machines (TSVM). Nucleic Acids Res 33:5799-5808

Risse D, Beiderbeck H, Taraz K, Budzikiewicz H, Gustine D (1998) Corrugatin, a lipopeptide from Pseudomonas corrugata. Z Naturforsch C 53:295-304

Schlegel K, Fuchs R, Schäfer M, Taraz K, Budzikiewicz H, Geoffroy V, Meyer JM (2001) The pyoverdins of Pseudomonas sp. 96-312 and 96-318. Z Naturforsch C 56:680-686

Schnider-Keel U, Seematter A, Maurhofer M, Blumer C, Duffy B, Gigot-Bonnefoy C, Reimmann C, Notz R, Défago G, Haas D, Keel C (2000) Autoinduction of 2,4-diacetylphloroglucinol biosynthesis in the biocontrol agent Pseudomonas fluorescens CHA0 and repression by the bacterial metabolites salicylate and pyoluteorin. J Bacteriol 182:1215-1225

Schwyn B, Neilands JB (1987) Universal chemical assay for the detection and determination of siderophores. Anal Biochem 160:47-56

Singh GM, Fortin PD, Koglin A, Walsh CT (2008) Beta-Hydroxylation of the aspartyl residue in the phytotoxin syringomycin E: characterization of two candidate hydroxylases AspH and SyrP in Pseudomonas syringae. Biochemistry 47:11310-11320

Stachelhaus T, Mootz HD, Marahiel MA (1999) The specificityconferring code of adenylation domains in nonribosomal peptide synthetases. Chem Biol 6:493-505

Sultana R, Fuchs R, Schmickler H, Schlegel K, Budzikiewicz H, Siddiqui BS, Geoffroy V, Meyer JM (2000) A pyoverdine from Pseudomonas sp. CFML 95-275. Z Naturforsch C 55:857-865

Tamura K, Peterson D, Peterson N, Stecher G, Nei M, Kumar S (2011) MEGA5: molecular evolutionary genetics analysis using maximum like-lihood, evolutionary distance, and 
maximum parsimony methods. Mol Biol Evol 28: 2731-2739

Tappe R, Taraz K, Budzikiewicz H, Meyer JM, Lefèvre JF (1993) Structure elucidation of a pyoverdin produced by Pseudomonas aeruginosa ATCC 27853. J Prakt Chem 335:83-87

Uría-Fernández D, Geoffroy V, Schäfer M, Meyer JM, Budzikiewicz H (2003) Structure revision of pyoverdines produced by plant-growth promoting and plant deleterious Pseudomonas species. Monatsh Chem 134:1421-1431

Van Der Voort M, Meijer HJ, Schmidt Y, Watrous J, Dekkers E, Mendes R, Dorrestein PC, Gross H, Raaijmakers JM (2015) Genome mining and metabolic profiling of the rhizosphere bacterium Pseudomonas sp SH-C52 for antimicrobial compounds. Front Microbiol 6:693

Vieira J, Messing J (1991) New pUC-derived cloning vectors with different selectable markers and DNA replication origins. Gene 100:189-194

Voisard C, Bull C, Keel C, Laville J, Maurhofer M, Schnider U, Défago G, Haas D (1994) Biocontrol of root diseases by Pseudomonas fluorescens CHA0: current concepts and experimental approaches. In: O'Gara F, Dowling D, Boesten B (eds) Molecular ecology of rhizosphere microorganisms. VCH, Weinheim, pp 67-89
Yamamoto S, Ksai H, Arnold DL, Jackson RW, Vivian A, Harayama S (2000) Phylogeny of the genus Pseudomonas: intrageneric structure reconstructed from the nucleotide sequences of $g y r B$ and $r p o D$ genes. Microbiology 146:2385-2394

Ye L, Ballet S, Hildebrand F, Laus G, Guillemyn K, Raes J, Matthijs S, Martins J, Cornelis P (2013) A combinatorial approach to the structure elucidation of a pyoverdine siderophore produced by a Pseudomonas putida isolate and the use of pyoverdine as a taxonomic marker for typing $P$. putida subspecies. Biometals 26:561-575

Ye L, Matthijs S, Bodilis J, Hildebrand H, Raes J, Cornelis P (2014a) Analysis of the draft genome of Pseudomonas fluorescens ATCC 17400 indicates a capacity to take up iron from a wide range of sources, including different exogenous pyoverdines. Biometals 27:633-644

Ye L, Hildebrand F, Dingemans J, Ballet S, Laus G, Matthijs S, Berendsen R, Cornelis P (2014b) Draft genome sequence analysis of a Pseudomonas putida W15Oct28 strain with antagonistic activity to Gram-positive and Pseudomonas sp. pathogens. PLoS One 9(11):e110038

Zerbino DR, Birney E (2008) Velvet: algorithms for de novo short read assembly using de Bruijn graphs. Genome Res 18:821-829 